\title{
Experimental Study on Offspring of Wistar Strain Rats Treated with Antithyroid Medication (Methiocil) for Successive Generations
}

By

\section{Hajime ARAI}

Department of Pathology, School of Medicine, Kyoto University (Director : Prof. Kôzô Okamoto)

A total of 10 Wistar rats, 5 females and 5 males, 90 days of age, were given intramuscular injections of methiocil in a daily dose of $7.5 \mathrm{mg} / 100 \mathrm{~g}$ for 3 days, and subsequently $10 \mathrm{mg} / 100 \mathrm{~g}$ for 32 days.

Examinations, morphological and physiological, on functions of the thyroid of the animals exposed to methiocil, revealed that the standard procedures of methiocil administration mentioned above could result in hypofunction of the thyroid.

Male and female Wistar rats treated with methiocil in the standard fashion were mated to obtain $\mathrm{F}_{1}$ animals (offspring).

These $\mathrm{F}_{1}$ animals, when 90 days old, were also treated with methiocil in the standard fashion, and were mated to obtain $F_{2}$ animals (Second generation offspring). $F_{3}$ and $F_{4}$ animals (successive generations) were obtained also by the same procedures.

Measurements of the body weight, serum PBI, total cholesterol and $\mathrm{I}^{191}$ uptake, and histological and histometrical studies on the thyroid gland and other endocrine organs were performed in 17, 14, 14 , and 11 cases of the $\mathrm{F}_{1}, \mathrm{~F}_{2}, \mathrm{~F}_{3}$ and $\mathrm{F}_{4}$ animals, respectively, and in 37 cases of normal rats.

The results obtained illustrate that a progressively increasing hypofunction of the thyroid gland could be induced in offspring rats treated with methiocil for successive generations.

\section{On Excretion of 17-KS and Uropepsin of Rabbits and Wistar Rats Born from Diabetic Parents for Successive Generations and on Effect of Alloxanization on the Excretion}

By

\section{Nobuko ISHIZAKI}

Department of Pathology, School of Medicine, Kyoto University (Director : Prof. Kôzô Okamoto)

Measurement of a total of 17-KS and its fractions excreted in the urine was made on the rabbits obtained from the diabetic parents by successive mating for seven or eight generations. Some of these rabbits were under the examination 50 to 365 days after an additional treatment with alloxan was employed. The following results were demonstrated, comparing with the data from control rabbits with or without alloxanization.

a) In the rabbits born from the sicked parents an increase in amount of 17-KS and II, III, VI, VII fractions were observed. The increase became more apparent with the successive mating generations and it was very marked in after the fourth generation in which spontaneous diabetes developed. 
b) Amounts of $17-\mathrm{KS}$ and its II, III, VI, VII fractions in the intact rabbits became under the normal levels when diabetes developed after administration of alloxan.

c) Amounts of $17-\mathrm{KS}$ and its II, III, VI, VII fractions excreted in the urine in the rabbits born from the sicked parents up to the second generation showed a decrease after alloxan administration, which were larger than those excreted in the urine of the alloxanized control rabbits and which were smaller than those of normal rabbits. However, in the rabbits from the sicked parents from the third to the fifth generations of the successive mating, a decrease in amounts of 17-KS and its II, III, VI, VII fractions was resulted from alloxanization, remaining at the level above normal ranges. Measurement of a total amounts of $17-\mathrm{KS}$ and its fractions, FGS and uropepsin were made on the following animals (I) the first group, Wistar rats with spontaneous diabetes in both sexes born from the spontaneous diabetic parents, at definite intervals of time from the weanling age to approximately 120 days of age. (2) the second group, some of the male rats of the first group, exposed to alloxanization when the animals showed negative urine sugar. The following results were obtained, comparing with the data from normal rats with or without alloxanization.

a) In Wistar rats of the first group, larger amounts of 17-KS and its II, III, VI, VII fractions, FGS and uropepsin were excreted in the urine than those in the normal rats during a full course of maturation and aging since weanling age.

b) In normal rats with alloxanization, an increase in amount of the metabolites mentioned herein observed 10 days after the treatment was followed by a persistent decrease.

c) The male rats in the second group, alloxanization also resulted in a temporary increase in the urinary amounts, subsequently followed by a decrease, continuing for at least 3 months, amounts in the decreasing stages still being remained in over normal ranges.

The following conclusions may be obtained from the results mentioned above :

1) In the offspring rabbits and Wistar rats born from diabetic parents, the hyperfunction of the adrenal cortex can be observed, the degree of 'which being gradually more apparent with successive mating generations.

2) The hypofunction of the adrenal cortex can be developed in the animals when rabbits and Wistar rats were became diabetic by application of alloxan.

3) The offsprsng animals born from the diabetic parents, when alloxanization is employed, show various function states, from hyper- to hypo-function to less extent, corresponding to the generation number of the successive mating. 


\section{歴代実験的糖尿病子孫ウサギおよびWistar系シロネズえの 尿中ケトステロイド，ウロペプンンの排泄状態ならびに アロキサン投与による影響について}

宗都大学医学部病理学教空（指導 岡实耕造教授）

石崎延子

（本論文の要旨は管33回日本内分泌学会総会に扔いて発表した）

\section{第 1 章 緒言}

最近副腎皮質より糖質代謝に密接な関係のあるグルココルチコイドが分泌されることが明らかにされ，糖 尿病之副腎皮質機能との関係について注目されるようになつた。こして人体糖尿病のさいの尿中ケトステロ

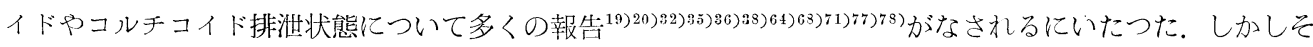
の結果は必ずし屯一致をみていない，乙れは糖尿病の病型の差，二次的変化，発症時期の相違などの要素が 関係しているためではなからうかと考光られる。乙れらの点老明らかにするには当然実験的糖㞘病動物につ いてその副腎皮質機能を精細に研究することが必要となつてくるのである。しかし糖尿病の発症には先天性 因子が重要な 1 因子をなしているものと考光られ，岡本 ${ }^{55}$ の構想にああるように後天性発症因子によつて， また先天性発症因子によつて発症を及る場合のほか，さらに先天性糖尿病素因に後天性発症因子か加わつて 発症をみる場合も少くないあのと考光られる。したがつて膵臟摘出や，アロキサン等による勝ラ氏島傷害に より発症した従来の実験的糖永病動物の知見のみでは，人体糖尿病のさいの副腎皮所機能の解明に充分でな いものと考えられる。

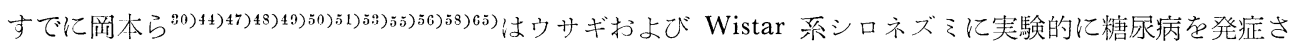
せ，一カ月以上糖尿病を持続させた後交配して仔を生ませ，この仔にてれをくり返し，歴代にわたり糖尿病 を発症させた子孫䃼物について研究した結果, 乙れらの子孫動物では膵う氏島 $\beta$-細胞の減数, 縮小などの発 育障碍, 脳下垂体, 副腎皮質等の一定の病理学的変化など糖尿病素因の生成があり, しかもそ机が累代性に 增強してりき, ついに糖尿病を自然発症することをみた. そしてての実験的先天性糖尿病動物の病理学的所 見が人体糖尿病の所見に非常に近いととを報告している。ささらにそのウサギの副腎皮質を病理学的に研究し た篗野ら ${ }^{66)}$ ，福留 ${ }^{21}$ は機能充進像を報告し，そして鈴木 $\left.{ }^{67}\right)$ はこれらのウサギの尿中17-KS総量が対照正常ウ サギより増量を示すととから副腎皮質の機能充進を推定し, すすんで赤沢 ${ }^{11}$ は17-KS 総量の増量のほか，そ のII, III, II, III分劃, 17-OHCS, ウロペプシンの增量を報告した。 すなわちこれらのウサギで糖尿病未発 症時期から糖尿病自然発症時にかけて副腎皮質機能は元進し，アロキサン糖尿病ウサギや正常り将ギにくら ベてケトステロイド代謝を異にしていると結論している。

ト述の上うに睍在までアロキサン糖尿病ウサギまたは実験的先天性糖尿病り少ギを用いて副腎皮質機能こ の他に関する諸種の研觉が行われてきたのであるが，しかし先天性糖尿病素因に後天性因子が加わつて発症

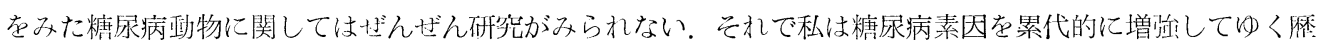
代糖尿病子孫ウサギまたは Wistar 系シロネズミを用い，乙机アロキサンを投与して糖尿病を発症させ， 発症後のケトステロイド代謝の変化を追究し，また下垂体副腎系の機能を間接的に示すとされている尿中り ロパプシンの測定を行つて，乙れを正常および正常政物にアロキサン糖尿病を発症させたさい，ならびに実 験的先天性糖沓病㢦物の成績上比較検討するとととした次第である。 


\section{第 2 章 歴代両親実験的糖尿病子孫ウサギにアロキサン糖尿病を 発症させたさいの尿中17-KS 総量および分劃について}

\section{第 1 節 研究材料}

1）対照正常ウサギ

教室で妊娠分婏させて得て正常ウ少ギおよび生後日数の明らかなり少ギを業者より購入し一定期間教室で

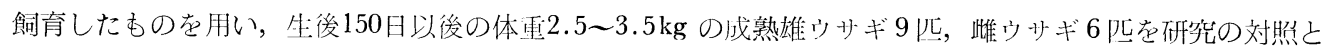
した.

\section{2) 歴代両親実験的糖尿病子孫ウサギ亡実験的先天性糖尿病子孫ウサギ}

歴代再親実験的糖尿病子孫ウサギ（ $\mathrm{f}$ で示す）は次のようにして作製した，正常成熟雄，倠ウサギにアロキ サン (Eastman Kodak 製 Alloxan monohydrate を使用した，以下ウサギでは同様試薬を使用)を $100 \mathrm{mg} /$ $\mathrm{kg}$ 静脈内に投与して糖尿病を炎症させ, その雄 2 , 雌 2 在とり 1 力月以上尿糖顕著陽性(州)(尿糖の判定には Benedict 氏試薬 ${ }^{23}$ を用い，試薬 $3 \mathrm{cc}$ 亿尿 6 滴を加えて加温し，惹沸後なお 2 分間加熱し，放置冷却後次の 基準によつて判定した，液が青色で沈澱のない場合を(一), 液が青緑色で沈瑖のない場合 (土), 液が青緑色

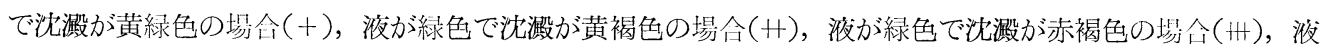
が無色で沈溉が赤色となる場合(册)) を持続した後交配してその仔 $\mathrm{f}_{1}$ を得(系図 1 参照), その生後 120 日以上 経た後, これら雄 2 , 雌 1 亿アロキサン $85 \mathrm{mg} / \mathrm{kg}$ を静脈内に投与し糖尿病持続 1 カ月以上して交配して $\mathrm{f}_{2}$ を得, $\mathrm{f}_{2}$ の雄, 雌各 2 亿アロキサンを $80 \mathrm{mg} / \mathrm{kg}$ 静脈内に投与し, 糖尿病持続 1 力月以上して交配し $\mathrm{f}_{3}$ を得 た.

$\mathrm{f}_{4}$ は小関58)の作製した 4 代 p-(Hydroxyphenylazo)-8-hydroxyquinoline 糖尿病子孫ウサギを使用した.

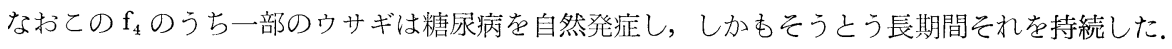

こ机ら $\mathrm{f}_{1}$ 〜 $\mathrm{f}_{4}$ ウサギのうち生後 150 日以後のあので体重 $2.5 \mathrm{~kg}$ 以上のものを私の研究に使用したが，その うちわけは次のようである。㱷は AF103, AF108 の 2 匹で雌は AF101, AF102, AF104, AF105 の4 匹

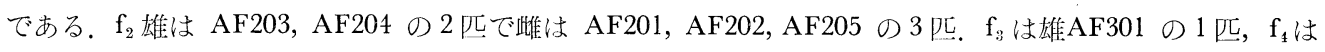
小関の作製した雌11464，11467の 2 匹である.

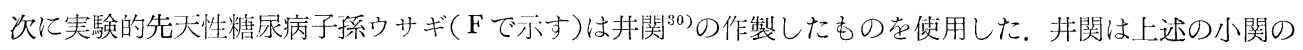
作製した 4 代子孫ウサギの糖疗病を自然発症したあのを $\mathrm{F}_{1}$ とし，なお他の 4 代子孫りサギで糖尿病を発症 しないか，発症してもてれを持続しなかつたものにさらにアロキサンを投与し糖永病持続 1 力月以上してそ の雄, 脽を父配して仔を生ませそれを $\mathrm{F}_{1}$ とし, 乙れら $\mathrm{F}_{1}$ で糖疗病存自然発症した雄, 雌を糖沓病持続 1 力 月以上して交配して生まれた仔を $\mathrm{F}_{2}$ とし，さらに同㥞にして $\mathrm{F}_{3} ， \mathrm{~F}_{4}$ 在得た。 これら $\mathrm{F}_{1} \sim \mathrm{F}_{4}$ の作製状態は系 図 1 に示したが，それらのうち生後150日以後で体重 $2.5 \mathrm{~kg}$ 以上のあのを私の研栄に使用した。すすおち $\mathrm{F}_{1}$

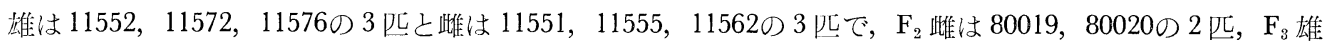
は90031，90035の 2 匹で雌は90032，90033，90034の 3 匹，F雄は100002，100004の 2 匹と雌100008である.

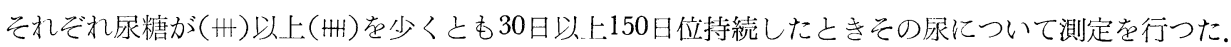

\section{3) アロキサン糖尿病ウサギ}

正常成熟雄, 雌ウサギにアロキサン $100 \mathrm{mg} / \mathrm{kg}$ 在静脈内に投与し糖尿病を発症させ尿糖顕著陽性を50日以 上100 日間持続した雄 4 匹と雌 3 匹を比較的短期のむのとして使用し，さらに 6 力月以上 1 年あまりにおよ ふ㳮糖顕著陽性を持続した雄 3 匹, 雌 5 匹を長期のむのとして用いた。

\section{4) 歴代両親実験的糖尿病子孫ウサギおよび実験的先天性糖尿病子孫ウサギの非発症時にアロキサン糖尿} 病を発症させた場合

これらの動物は全部成熟後にこれぞれてロキサンを $85 \mathrm{mg} / \mathrm{kg}$ ないし $60 \mathrm{mg} / \mathrm{kg}$ を静脈内に投与し，糖尿病 を発症させ，尿糖顕著陽性が少くとも50日以上 1 年位の間持続したものを研究材料とした(系図 1 参照)。す なわち $\mathrm{f}_{1}$ ウサギはアロキサン $85 \mathrm{mg} / \mathrm{kg}$ 芷投与した雄 $\mathrm{AF} 107, \mathrm{AF} 109$ と, 雌 $\mathrm{AF} 106, \mathrm{AF} 110$ の各 2 匹ずつ, 
系図 1 実験的先天性糖尿病子孫ウサギ系図

$\mathrm{P}$

$f_{1}$

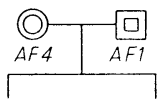

回 $\square$ 回 AF107 AF108 AF109 AF10

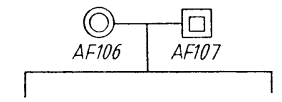

$f_{2}$

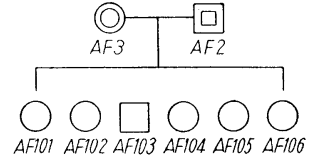

AF101 AF102 AF103 AF104 AF105 AF106

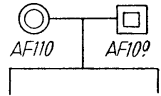

[0] (O)

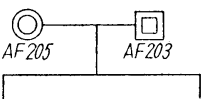

$f_{3}$

$$
\begin{array}{ccc}
\square & \square & \square \\
A F 301 & \square=303 & \text { AF304 }
\end{array}
$$
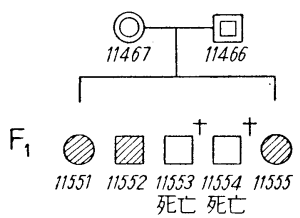
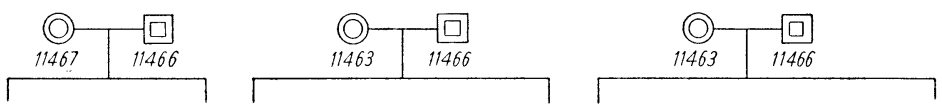

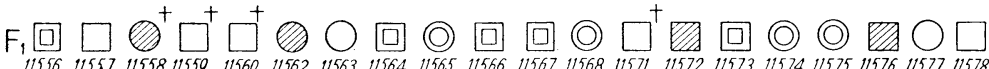

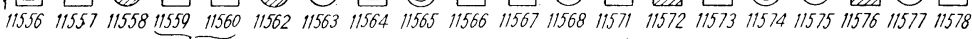
死亡 生直後死亡 死亡
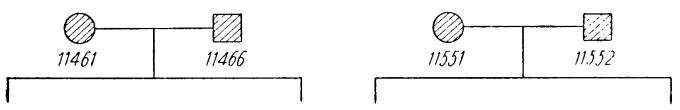

$F_{2}$
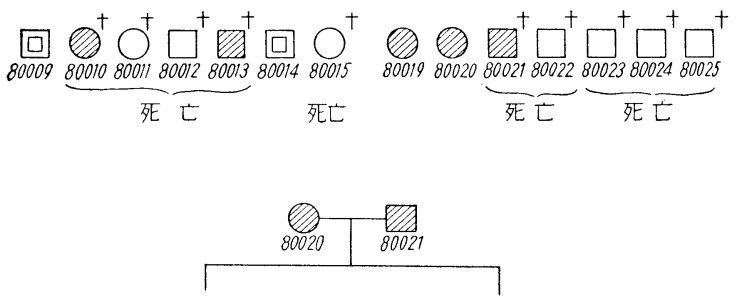

$F_{3}$
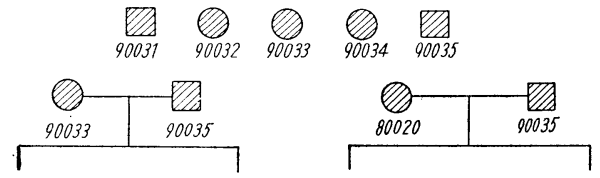

$\mathrm{F}_{4}$

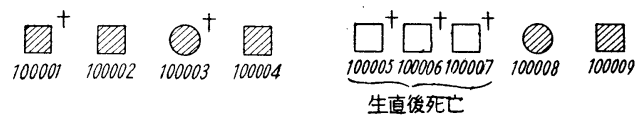

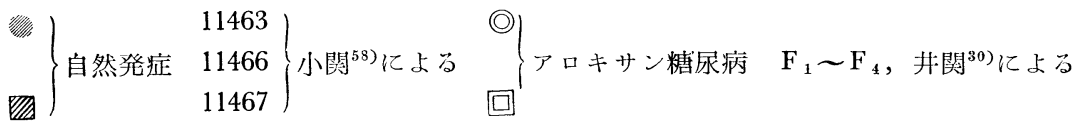




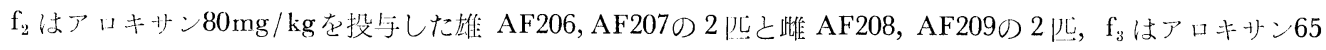
$\mathrm{mg} / \mathrm{kg}$ 在投与した雄 $\mathrm{AF} 303, \mathrm{AF} 304$ の儿， $\mathrm{f}_{4}$ はアロキサン $60 \mathrm{mg} / \mathrm{kg}$ を投与した倠11464，11467の 2 匹で ある.

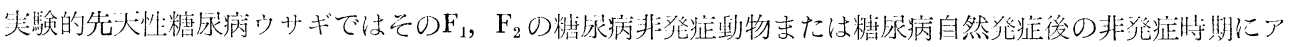

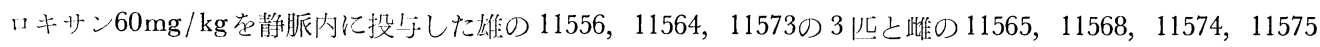

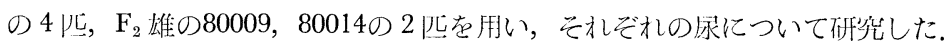

以上の䒠験使用したすべてのウサギは 1 儿宛飼育箱に入れ，オカラ，ムギ，二ンジン，雑幕を与光，健 康状態に留意した。冬李は室温に注意し，絶えず $20^{\circ} \mathrm{C}$ 内外に保温し，また換爻に注意した，夏は通風をよく し，できるだけ条件を一定にして飼育するようにした。また飼育箱は絶えず清潔にし感染，下瘌などをおこ さ彷上うに注意した。採尿は一定の採㽷箱在使用し，不純物の混入をさけ，しかも一定期間採尿箱で飼育し て尿量が一定した時期に行つた，尿の变性在防ぐため一日分の採尿の後值ちに氷室に保存し，48時間尿を集 わてただちに測定操作を行つた，各動物については 1 週 1 回体重測定を行つた.

\section{第 2 節 研究方法}

\section{1） ウサギ尿中17-KS総量ならびに分劃測定法}

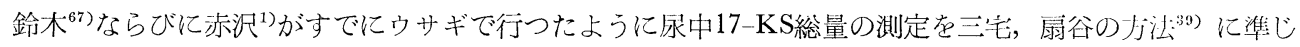

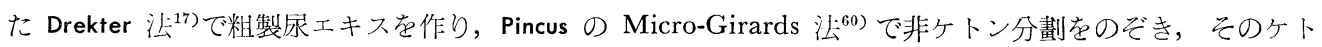
ン分劃について Pearson 洁 $^{59}$ 亿從い Zimmermann 反応 ${ }^{80881)}$ を行い日立光光度計 EPU-2 型を用い530m $\mu$ で比 色定量した。ささらに分劃については赤沢 ${ }^{1)} の$ 行つたように Pond ${ }^{(1)}$, Edwards, ${ }^{18)}$, 大野 ${ }^{57)}$ の方汒汇従つて, そのケトン分劃について Liquid Column Partition Chromatography を行つた.

\section{2) 統計学的検定}

\section{次の方法 ${ }^{33)}$ で行つた。}

$$
\mathrm{t}=\frac{\mathrm{x}-\mathrm{y}-\mathrm{a}}{\sqrt{\mathrm{n}_{1} \mathrm{~S}_{1}{ }^{2}+\mathrm{n}_{2} \mathrm{~S}_{2}{ }^{2}}} \quad \sqrt{\frac{\mathrm{n}_{1} \mathrm{n}_{2}\left(\mathrm{n}_{1}+\mathrm{n}_{2}-2\right)}{\mathrm{n}_{1}+\mathrm{n}_{2}}}
$$

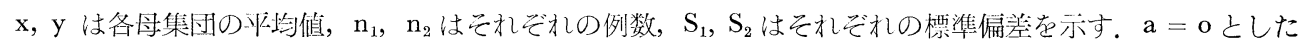
時の $\mathrm{t}$ の值を上式から計算し， $\mathrm{p}=0.01$ にたいして $\mathrm{t}$ 分布表による $\mathrm{t}_{0}$ の值をむとめ $\mathrm{t} \geqq \mathrm{t}_{0}$ ならば有意の差が あるとし， $\mathrm{t}<\mathrm{t}_{0}$ ならば有意の差がないとした。

第 3 節 研究成績 (第 1,2 表, 第 1,2 図参照)

\section{第 1 項＼cjkstart無処置群の尿中17-KS総量ならびに分劃}

1) 対照正常ウサギ

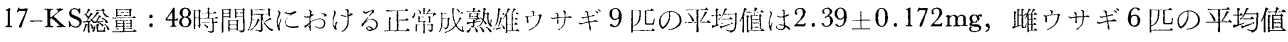

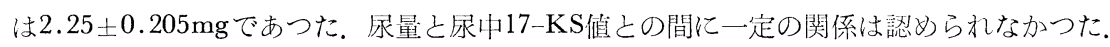

尿中 17-KS 分劃：48時間尿における雄の $\mathrm{I}+\mathrm{V}$ 分劃は排泄量の百分率，絶体值でるると $48.5 \%, 1.16 \pm$ $0.061 \mathrm{mg}$ で雔のそれは $33.2 \%, 0.75 \pm 0.089 \mathrm{mg}$ であり, 雄か淮より大量の Testosterone, Etiocholanolone を排泄している。、分劃では雌が $20 \%, 0.45 \pm 0.051 \mathrm{mg}$ で雄の $15 \%, 0.36 \pm 0.037 \mathrm{mg}$ より大で膗は 11-oxy17-KS の排泄が多い.

2) 歴代両視実験的糖尿病子孫ウサギ（ $\left.\mathrm{f}_{1} \sim \mathrm{f}_{4}\right)$

尿中17-KS総量 : 48時間尿について $\mathrm{f}_{1}$ 雄は $2.61 \pm 0.076 \mathrm{mg}$, 雌は $2.40 \pm 0.088 \mathrm{mg}, \mathrm{f}_{2}$ 雄は $2.76 \pm 0.046 \mathrm{mg}$, 雌は $2.51 \pm 0.058 \mathrm{mg}, \mathrm{f}_{3}$ 雄は $3.10 \pm 0.110 \mathrm{mg}$ 之増加傾向を示し, $\mathrm{f}_{4}$ 雌では $4.54 \pm 0.215 \mathrm{mg}$ で対照正常ウサギ のほば 2 倍に達している。

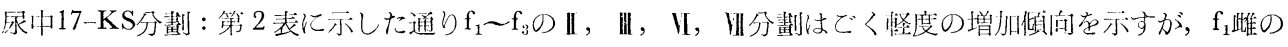

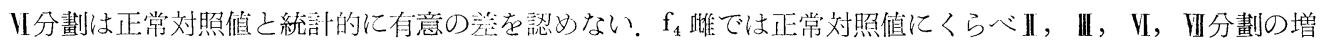

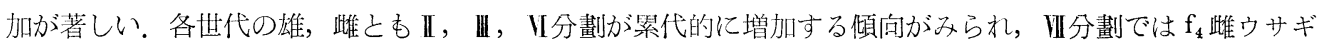


歴代実験的糖尿病子孫ウサギ扔よび Wistar 系シロネズミの尿中ケトステロイド， ウロペプシンの排泄状態ならびにアロキサン投与による影響について（石崎）

第 1 表 実験的先天性糖尿病子孫ウサギ扣よび正常ウサギにアロキサン糖尿病を 発症させたさいの尿中17-KS総量 A ‥アロキサン糖尿病発症

\begin{tabular}{|c|c|c|c|c|c|c|c|c|c|}
\hline \multirow[b]{2}{*}{ 世 } & \multirow[b]{2}{*}{ 代 } & \multicolumn{4}{|c|}{ 雄 } & \multicolumn{4}{|c|}{ 雌 } \\
\hline & & 匹数 & $\begin{array}{ll}\text { 測 定 } \\
\text { 日 数 }\end{array}$ & $\left|\begin{array}{l}\text { アロキサン投 } \\
\text { 与量 } \\
\text { (mg/48時間) }\end{array}\right|$ & $\left|\begin{array}{c}17-\mathrm{KS} \text { 総 量 } \\
(\mathrm{mg} / 48 \text { 時間 })\end{array}\right|$ & 匹数 & $\begin{array}{ll}\text { 測 定 } \\
\text { 回 数 }\end{array}$ & $\begin{array}{l}\text { アロキサン投 } \\
\text { 与量 } \\
\text { ( } \mathrm{mg} / 48 \text { 時間) }\end{array}$ & $\begin{array}{l}17-\mathrm{KS} \text { 総 量 } \\
(\mathrm{mg} / 48 \text { 時間 })\end{array}$ \\
\hline 正 & 常 & 9 & $(30)$ & & $2.39 \pm 0.172$ & 6 & (15) & & $2.25 \pm 0.205$ \\
\hline \multirow{2}{*}{ 正常 A } & 短期 & 4 & (12) & 100 & $1.40 \pm 0.205$ & 3 & (9) & 100 & $1.41 \pm 0.197$ \\
\hline & 長期 & 3 & (9) & 100 & $1.27 \pm 0.270$ & 5 & (15) & 100 & $1.07 \pm 0.305$ \\
\hline \multirow{2}{*}{$f_{1}$} & & 2 & ( 6$)$ & & $2.61 \pm 0.076$ & 4 & (12) & & $2.40 \pm 0.088$ \\
\hline & A & 2 & (6) & 85 & $1.37 \pm 0.121$ & 2 & (6) & 85 & $1.09 \pm 0.093$ \\
\hline \multirow{2}{*}{$f_{2}$} & & 2 & ( 6$)$ & & 2.76 上0.046 & 3 & (9) & & $2.51 \pm 0.058$ \\
\hline & $\mathrm{A}$ & 2 & ( 6$)$ & 80 & $1.63 \pm 0.104$ & 2 & (6) & 80 & $1.21 \pm 0.114$ \\
\hline \multirow{2}{*}{$f_{3}$} & & 1 & ( 5$)$ & & $3.10 \pm 0.110$ & & & & \\
\hline & $\mathrm{A}$ & 2 & (6) & 65 & $2.64 \pm 0.325$ & & & & \\
\hline \multirow{2}{*}{$\mathrm{f}_{4}$} & & & & & & 2 & ( 6$)$ & & $4.54 \pm 0.215$ \\
\hline & A & & & & & 2 & ( 6$)$ & 60 & $2.42 \pm 0.182$ \\
\hline \multirow{2}{*}{$\mathrm{F}_{1}$} & & 3 & (6) & & $4.61 \pm 0.245^{\dagger}$ & 3 & (9) & & $4.61 \pm 0.223$ \\
\hline & A & 5 & (10) & 60 & $2.62 \pm 0.305$ & 4 & (12) & 60 & $2.49 \pm 0.241$ \\
\hline $\mathrm{F}_{2}$ & A & 2 & ( 6$)$ & 60 & $2.70 \pm 0.263$ & 2 & ( 6$)$ & & $3.40 \pm 0.092$ \\
\hline \multirow{2}{*}{\multicolumn{2}{|c|}{$\begin{array}{l}\mathrm{F}_{3} \\
\mathrm{~F}_{4}\end{array}$}} & 2 & (6) & & $4.88 \pm 0.183$ & 3 & ( 6$)$ & & $3.43 \pm 0.186$ \\
\hline & & 2 & ( 6$)$ & & $4.92 \pm 0.129$ & 1 & (5) & & $3.82 \pm 0 \cdot 246$ \\
\hline
\end{tabular}

第 1 図実験的先天性糖尿病子孫ウサギにアロキサン糖疛病を発症させたさいの尿中 $17-\mathrm{KS}$ 総量 $\mathrm{mg} / 48$ 時間

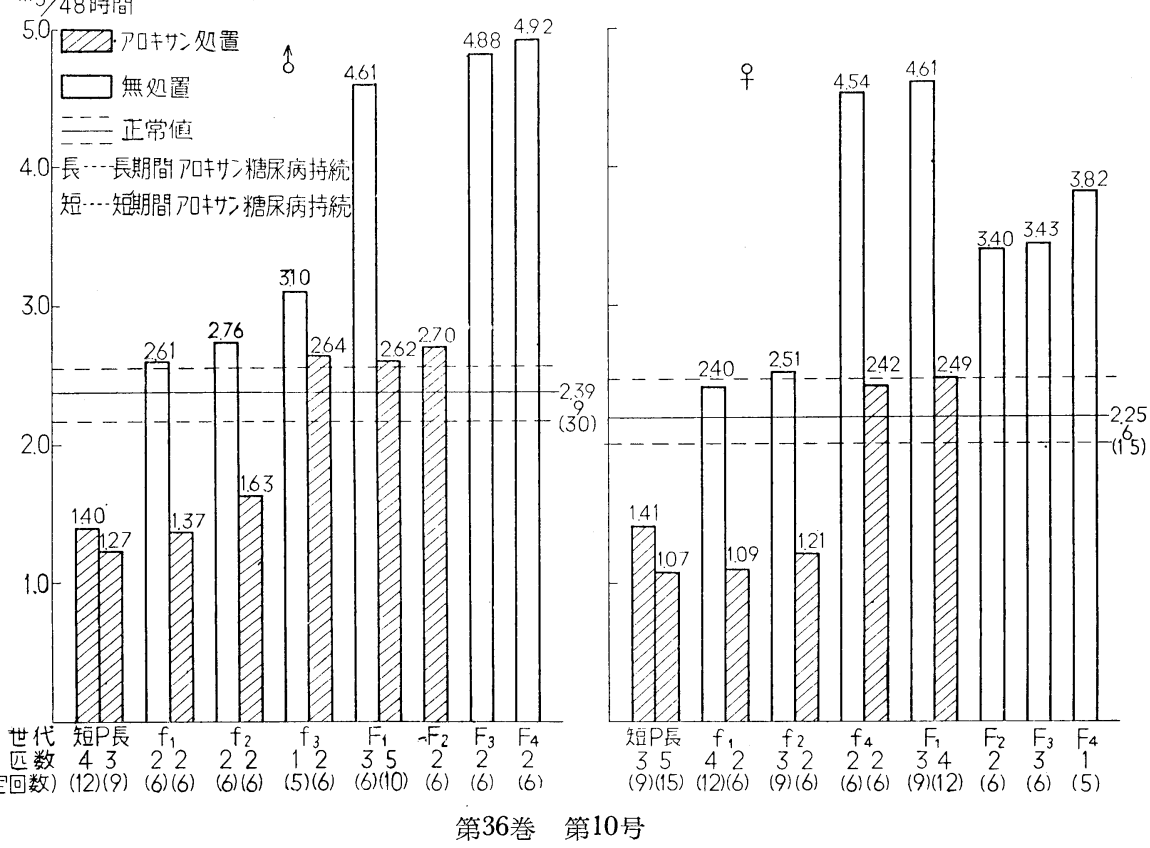


第 2 表 実験的先天性糖尿病子孫ウサギ执よび正常ウサギにアロキサン糖尿病を発症させたさいの尿中17-KS分劃

\begin{tabular}{|c|c|c|c|c|c|c|c|c|c|c|c|c|c|c|c|c|}
\hline \multirow{3}{*}{\multicolumn{2}{|c|}{ 世代 }} & \multirow{3}{*}{$\left(\begin{array}{ll}17-\mathrm{KS} \\
\text { 総 } \\
\mathrm{mg} / \mathrm{9} \\
\mathrm{mg} \\
\begin{array}{ll}\text { 量 } \\
\text { 時 }\end{array}\end{array}\right.$} & \multicolumn{14}{|c|}{ 17-KS分劃 （48時間值） } \\
\hline & & & \multicolumn{2}{|l|}{ I } & \multicolumn{2}{|l|}{ II } & \multicolumn{2}{|c|}{ III } & \multicolumn{2}{|c|}{$\mathrm{IV}+\mathrm{V}$} & \multicolumn{2}{|l|}{ II } & \multicolumn{2}{|l|}{$\mathbb{I A}$} & \multicolumn{2}{|l|}{ VIII } \\
\hline & & & $\mathrm{mg}$ & $\%$ & $\mathrm{mg}$ & $\%$ & $\mathrm{mg}$ & $\%$ & $\mathrm{mg}$ & $\%$ & $\mathrm{mg}$ & $\%$ & $\mathrm{mg}$ & $\%$ & $\mathrm{mg}$ & $\%$ \\
\hline 正 & & $\mid \begin{array}{c}2.39 \\
\pm 0.172\end{array}$ & $\begin{array}{c}0.12 \\
\pm 0.024\end{array}$ & 4.3 & $\mid \begin{array}{c}0.17 \\
\pm 0.021\end{array}$ & 7.1 & $\begin{array}{c}0.26 \\
\pm 0.025\end{array}$ & 10.9 & $\begin{array}{c}1.16 \\
\pm 0.061\end{array}$ & 48.5 & $\mid \begin{array}{c}0.36 \\
\pm 0.037\end{array}$ & 15.0 & $\mid \begin{array}{c}0.17 \\
\pm 0.060\end{array}$ & 6.9 & $\mid \begin{array}{c}0.16 \\
\pm 0.039\end{array}$ & 6.8 \\
\hline \multirow{2}{*}{ 正常 A } & 短 & $\mid \begin{array}{c}1.40 \\
\pm 0.305\end{array}$ & $\begin{array}{c}0.09 \\
\pm 0.025 \\
\end{array}$ & 6.4 & $\mid \begin{array}{c}0.15 \\
\pm 0.067\end{array}$ & 10.5 & $\begin{array}{c}0.20 \\
\pm 0.056\end{array}$ & 14.8 & $\begin{array}{r}0.57 \\
\pm 0.109 \\
\end{array}$ & $41.0 \mid$ & $\begin{array}{c}0.18 \\
\pm 0.027\end{array}$ & 13.0 & $\mid \begin{array}{c}0.09 \\
\pm 0.023\end{array}$ & 6.8 & $\mid \begin{array}{c}0.10 \\
\pm 0.038\end{array}$ & 7.5 \\
\hline & 長 & $\begin{array}{c}1.27 \\
\pm 0.270 \\
\end{array}$ & $\begin{array}{r}0.07 \\
\pm 0.016 \\
\end{array}$ & 5.5 & $\begin{array}{c}0.04 \\
\pm 0.084 \\
\end{array}$ & 3.2 & $\begin{array}{c}0.08 \\
\pm 0.025 \\
\end{array}$ & $6.3^{i}$ & $\begin{array}{c}0.88 \\
\pm 0.120\end{array}$ & 69.2 & $\begin{array}{c}0.09 \\
\pm 0.019\end{array}$ & 7.1 & $\begin{array}{c}0.03 \\
\pm 0.017\end{array}$ & & $\begin{array}{c}0.08 \\
\pm 0.028\end{array}$ & 6.3 \\
\hline \multirow{2}{*}{$f_{1}$} & & $\begin{array}{c}2.61 \\
\pm 0.076\end{array}$ & $\begin{array}{c}0.07 \\
\pm 0.050\end{array}$ & 2.9 & $\begin{array}{c}0.31 \\
\pm 0.044\end{array}$ & 12.0 & $\begin{array}{c}0.33 \\
\pm 0.060\end{array}$ & $|12.7|$ & $\begin{aligned} & 1.15 \\
\pm & 0.055\end{aligned}$ & 44.4 & $\begin{array}{c}0.42 \\
\pm 0.012\end{array}$ & 15.0 & $\begin{array}{c}0.26 \\
\pm 0.011\end{array}$ & & $\begin{array}{r}0 \\
\pm 0\end{array}$ & 2.2 \\
\hline & $\mathrm{A}$ & $\mid \begin{array}{c}1.37 \\
\pm 0.121\end{array}$ & $\begin{array}{l}0.13 \\
\pm 0.025\end{array}$ & 10.1 & $\mid \begin{array}{c}0.14 \\
\pm 0.018\end{array}$ & $\mid 10.8$ & $\begin{array}{c}0.20 \\
\pm 0.016\end{array}$ & $\mid 14.7$ & $\begin{array}{c}0.42 \\
\pm 0.052\end{array}$ & $|30.4|$ & $\begin{array}{c}0.24 \\
\pm 0.008\end{array}$ & $\mid 17.4$ & $\begin{array}{c}0.15 \\
\pm 0.068\end{array}$ & $10.6^{\prime}$ & $\begin{array}{r}0 \\
+ \pm 0\end{array}$ & 6.0 \\
\hline \multirow{2}{*}{$\mathrm{f}_{2}$} & & $\mid \begin{array}{c}2.76 \\
\pm 0.046 \\
\end{array}$ & $\begin{array}{c}0.11 \\
\pm 0.035 \\
\end{array}$ & & $\begin{array}{c}0.34 \\
\pm 0.031 \\
\end{array}$ & 12.4 & $\begin{array}{c}0.37 \\
\pm 0.038 \\
\end{array}$ & 13.5 & $\begin{aligned} & 1.75 \\
\pm & 0.027\end{aligned}$ & 41. & $\begin{array}{c}0.42 \\
\pm 0.030\end{array}$ & 15.2 & $\begin{array}{c}0.28 \\
\pm 0.017\end{array}$ & 9.9 & $\begin{array}{r}0 . \\
\pm 0 .\end{array}$ & 3.2 \\
\hline & $\mathrm{A}$ & $\begin{array}{c}1.63 \\
\pm 0.104 \\
\end{array}$ & $\begin{array}{c}0.11 \\
\pm 0.028 \\
\end{array}$ & & $\begin{array}{c}0.23 \\
\pm 0.012 \\
\end{array}$ & 14.5 & $\begin{array}{c}0.17 \\
\pm 0.004\end{array}$ & 10.4 & $\begin{aligned} & 0.58 \\
\pm & 0.040\end{aligned}$ & $|35.2|$ & $\begin{array}{c}0.26 \\
\pm 0.031\end{array}$ & 13.8 & $\begin{array}{c}0.14 \\
\pm 0.017\end{array}$ & 10.7 & $\begin{array}{r}0 \\
\pm 0\end{array}$ & 8.7 \\
\hline \multirow{2}{*}{$f_{3}$} & & $\begin{array}{c}3.10 \\
\pm 0.110 \\
\end{array}$ & $\begin{array}{c}0.12 \\
\pm 0.016 \\
\end{array}$ & 3.3 & $\begin{array}{c}0 . \overline{3} 6 \\
\pm 0.014\end{array}$ & 11.7 & $\begin{array}{c}0.38 \\
\pm 0.018 \\
\end{array}$ & $|12.3|$ & $\begin{aligned} & 1.18 \\
&+ 0.032 \\
&\end{aligned}$ & $|38.4|$ & $\begin{array}{c}0.62 \\
\pm 0.021 \\
\end{array}$ & $|20.0|$ & $\begin{array}{r}0 . \\
\pm 0\end{array}$ & 8.3 & $\begin{array}{r}0 \\
\pm 0 \\
\end{array}$ & 6.0 \\
\hline & A & $\begin{array}{c}2.64 \\
\pm 0.325\end{array}$ & $\begin{array}{c}0.24 \\
\pm 0.033\end{array}$ & 9.3 & $\begin{array}{c}0.29 \\
\pm 0.036\end{array}$ & $|10.7|$ & $\begin{array}{c}0.30 \\
\pm 0.025\end{array}$ & $\mid 11.3$ & $\begin{array}{c}0.87 \\
\pm 0.089\end{array}$ & $34.0 \mid$ & $\begin{array}{c}0.50 \\
\pm 0.065\end{array}$ & $\mid 18 \cdot 8$ & $\mid \begin{array}{c}0.17 \\
\pm 0.021\end{array}$ & 6.4 & $\begin{array}{c}0.27 \\
\pm 0.037\end{array}$ & 9.5 \\
\hline \multirow{2}{*}{$\mathrm{F}_{1}$} & & $\begin{array}{c}4.61 \\
\pm 0.245\end{array}$ & $\begin{array}{c}0.09 \\
\pm 0.007 \\
\end{array}$ & & $\begin{array}{c}0.70 \\
\pm 0.044\end{array}$ & 15.3 & $\begin{array}{c}0.74 \\
\pm 0.040 \\
\end{array}$ & 15.9 & $\begin{aligned} & 0.77 \\
& \pm 0.026 \\
&\end{aligned}$ & $\mid 16.5$ & $\begin{array}{r}1.08 \\
\pm 0.097 \\
\end{array}$ & 23.2 & $\begin{array}{c}1.02 \\
\pm 0.117\end{array}$ & 22.5 & $\begin{array}{c}0.21 \\
\pm 0.050\end{array}$ & 4.6 \\
\hline & $\mathrm{A}$ & $\mid \begin{array}{c}2.62 \\
\pm 0.305\end{array}$ & $\begin{array}{l}0.07 \\
+0.017\end{array}$ & 2.4 & $\begin{array}{c}0.39 \\
\pm 0.009 \\
\end{array}$ & $15.0^{1}$ & $\begin{array}{c}0.39 \\
\pm 0.012\end{array}$ & $|15.0|$ & $\begin{array}{c}0.71 \\
\pm 0.098\end{array}$ & $27.5 \mid$ & $\begin{array}{ll}0.48 \\
0.085\end{array}$ & 18.5 & $\begin{array}{c}0.49 \\
\pm 0.095\end{array}$ & $18 \cdot 7$ & $\begin{array}{c}0.09 \\
\pm 0.032 \\
\end{array}$ & 2.9 \\
\hline $\mathrm{F}_{2}$ & $\mathrm{~A}$ & $\mid \begin{array}{c}2.70 \\
\pm 0.263 \\
\end{array}$ & $\begin{array}{c}0.09 \\
\pm 0.012\end{array}$ & 3.2 & $\begin{array}{c}0.45 \\
\pm 0.041\end{array}$ & 16.0 & $\mid \begin{array}{c}0.42 \\
\pm 0.048\end{array}$ & 15.5 & $\begin{array}{c}0.59 \\
\pm 0.064 \\
\end{array}$ & 22.0 & $\begin{array}{c}0.48 \\
\pm 0.052\end{array}$ & 17.8 & $\begin{array}{c}0.49 \\
\pm 0.045\end{array}$ & 18.0 & $\begin{array}{c}0.19 \\
\pm 0.019\end{array}$ & 7.0 \\
\hline \multicolumn{2}{|l|}{$\mathrm{F}_{3}$} & $\begin{array}{c}4.88 \\
\pm 0.183\end{array}$ & $\begin{array}{c}0.14 \\
\pm 0.017\end{array}$ & 2.7 & $\begin{array}{c}0.71 \\
\pm 0.032\end{array}$ & 14.1 & $\begin{array}{c}0.62 \\
\pm 0.014\end{array}$ & $|12.5|$ & $\begin{array}{c}1.12 \\
+0.144\end{array}$ & $\mid 23.0$ & $\begin{array}{c}0.88 \\
\pm 0.093 \\
\end{array}$ & 18.0 & $\begin{array}{c}1.23 \\
\pm 0.147\end{array}$ & 25.0 & $\begin{array}{c}0.19 \\
\pm 0.015\end{array}$ & 3.5 \\
\hline \multicolumn{2}{|l|}{$\mathrm{F}_{4}$} & $\begin{array}{c}4.92 \\
\pm 0.129\end{array}$ & $\begin{array}{c}0.13 \\
\pm 0.007\end{array}$ & 2.8 & $\begin{array}{c}0.64 \\
\pm 0.019\end{array}$ & $\mid 13.0$ & $\mid \begin{array}{c}0.62 \\
\pm 0.022\end{array}$ & & $\begin{array}{c}1.17 \\
\pm 0.089\end{array}$ & 24.0 & $\begin{array}{c}1.12 \\
\pm 0.128\end{array}$ & & $\begin{array}{c}1.04 \\
\pm 0.147\end{array}$ & 20.5 & $\begin{array}{c}0.20 \\
\pm 0.019\end{array}$ & 4.0 \\
\hline
\end{tabular}

$$
\text { B 雌ウサギ }
$$

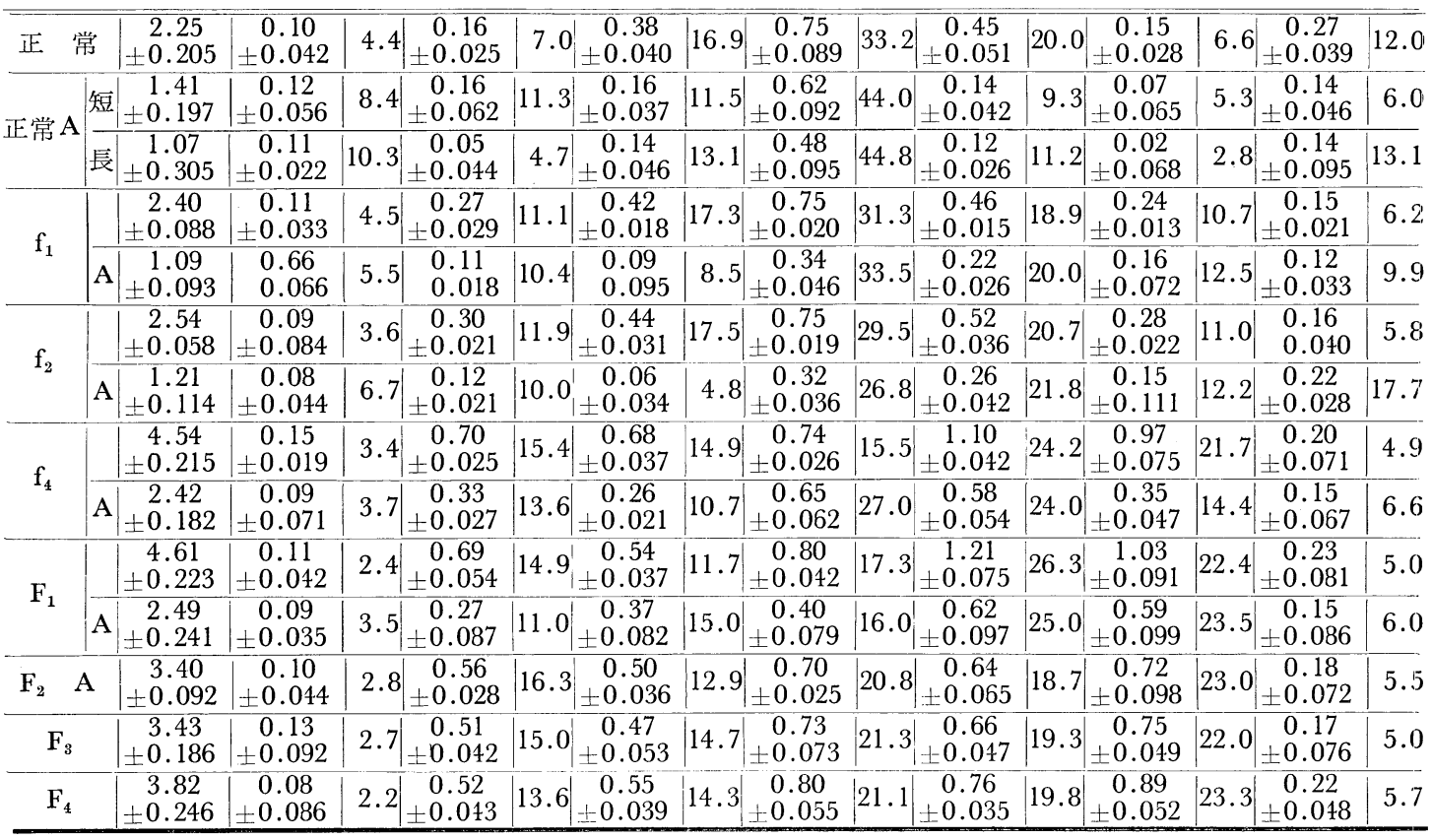


第 2 図 実験的先天性糖尿病子孫ウサギにアロキサン糖尿病を発症させたさいの尿中 $17-\mathrm{KS}$ 分劃 $\mathrm{mg} / 48$ 㫱間
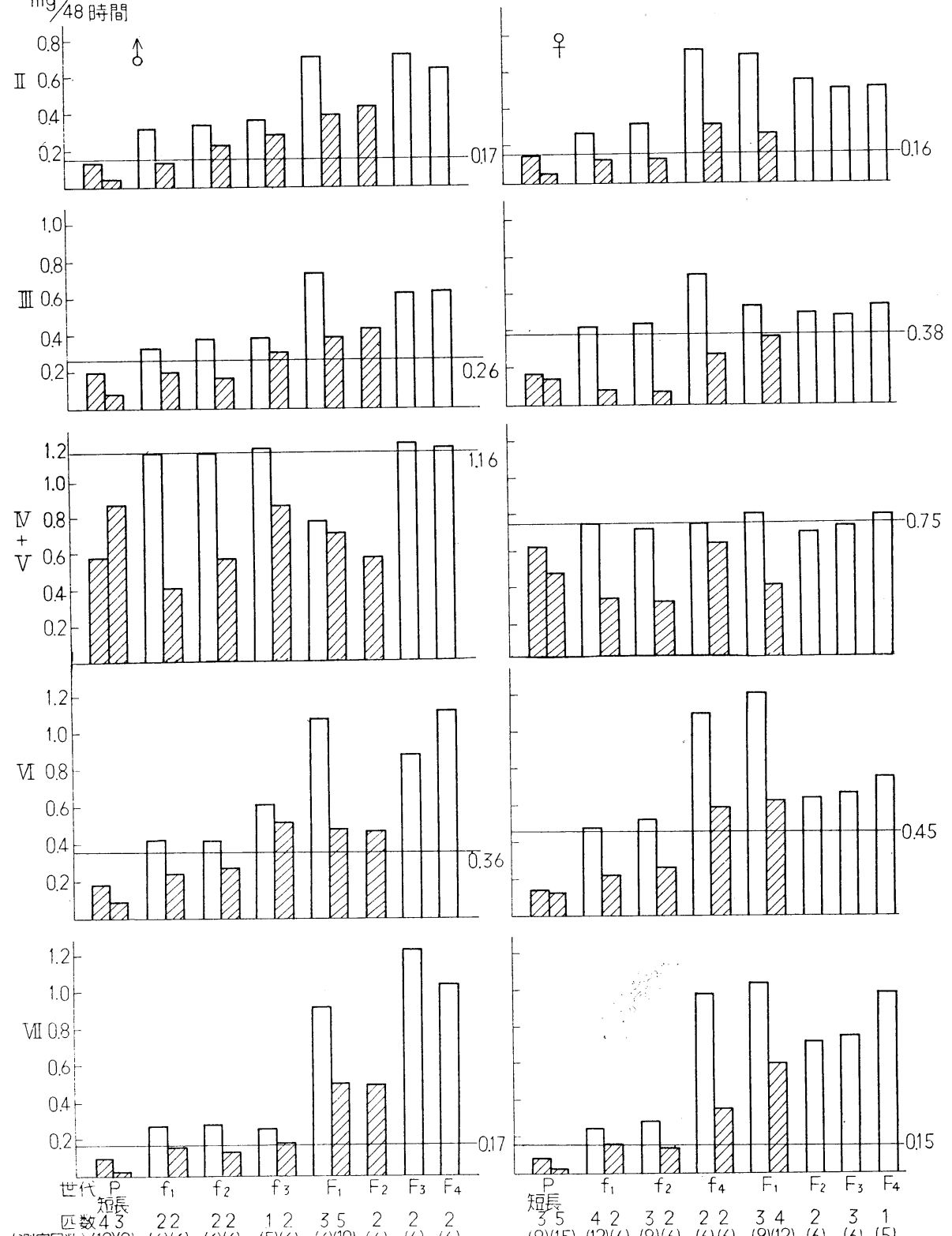

(測定回数) (12)(9) $(6)(6) \quad(6)(6) \quad(5)(6) \quad(6)(10)(6) \quad(6) \quad(6)$

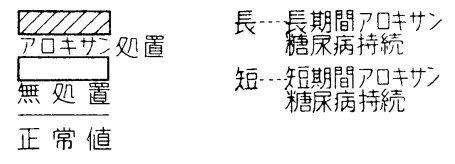

が著增を示しその他は軽度の增加を示す。

3）実験的先天性糖尿病子孫りサギ $\left(\mathrm{F}_{1} \sim \mathrm{F}_{4}\right)$ 
尿中17-KS総量 $: \mathrm{F}_{1}, \mathrm{~F}_{2}, \mathrm{~F}_{3}, \mathrm{~F}_{4}$ の各世代の糖尿病自然発症ウサギでは対照正常ウサギにくらべさらに著明 な17-KS総量の増加がみられる。 48時間尿における17-KS総量は $\mathrm{F}_{1}$ 雄 $4.61 \pm 0.245 \mathrm{mg}$, 倠は $4.61 \pm 0.223 \mathrm{mg}$, $\mathrm{F}_{2}$ 雌は $3.40 \pm 0.092 \mathrm{mg}, \mathrm{F}_{3}$ 雄 $4.88 \pm 0.183 \mathrm{mg}$, 雌は $3.43 \pm 0.186 \mathrm{mg}, \mathrm{F}_{4}$ 雄 $4.92 \pm 0.129 \mathrm{mg}$, 雌は $3.82 \pm$ $0.246 \mathrm{mg}$ であつた. いずれも正常值の1.5〜2 倍の増量を示した.

尿中17-KS分劃：第 2 表に示したように $\mathrm{F}_{1}, \mathrm{~F}_{2}, \mathrm{~F}_{3}, \mathrm{~F}_{4}$ とも II III, VI, III分劃の百分率および絶体值の 増加がみられる。

\section{第 2 項 アロキサン投与群の尿中17-KS総量ならびに分劃}

1）正常ウサギにアロキサン糖尿病を発症させた場合

尿中17-KS 総量 : アロキサン糖尿病発症後50日から 100 日位の比較的短期間のものの48時間尿については 雄 $1.40 \pm 0.305 \mathrm{mg}$, 雌 $1.41 \pm 0.197 \mathrm{mg}$ である. 6 力月以上の長期アロキサン糖尿病を持続したあのの雄 1.27 $\pm 0.270 \mathrm{mg}$, 雔 $1.07 \pm 0.305 \mathrm{mg}$ である.アロキサンを投与しない正常値之比較して, いずれも著明な城少を

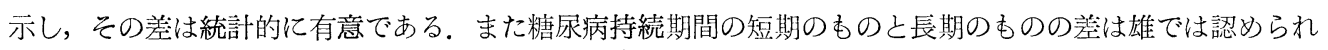
ないが，雌では認められる。

尿中17-KS 分劃: 50 日から 100 日間位糖尿病持続の比較的短期間のものの雄, 雌とも II 分劃が正常範囲に とどまる以外はVI， III分劃の減少が著しく正常值とは統計的に有意の著があり，なお長期のあのも同様であ る.アロキサン糖尿病発症後の時間的な差については雌のV分劃において相互間に有意の差がない以外全分 劃において長期のあのが低下を示している.

2) 歴代両親実験的糖尿病子孫ウサギにアロキサン糖尿病を発症させた場合.

尿中17-KS総量 : 48時間尿について $\mathrm{f}_{1}$ ウサギのアロキサン糖尿病の雄平均 $1.37 \pm 0.121 \mathrm{mg}$, 雌平均 $1.09 \pm$ $0.093 \mathrm{mg}$ でいずれもアロキサンを投与しないむのより著しく減少し, 正常ウサギにアロキサン糖尿病を発症 させた場合と比較し, その長期のものとは統計的に雌では有意の差はなく, 雄は有意の差を示して増加して いる， $\mathrm{f}_{2}$ ウサギのアロキサン糖尿病の雄平均 $1.63 \pm 0.104 \mathrm{mg}$, 雌平均 $1.21 \pm 0.114 \mathrm{mg}$ で, 無処置のものにく らべ明らかな減少がみられるが，正常ウサギにアロキサン糖㽷病を発症させたものより雄，雌とも統計的に 有意の差を示し增加している．また $f_{1}$ ウサギのアロキサン糖尿病の場合より有意の差を示して增加してい る. $\mathrm{f}_{3}$ ウサギのアロキサン糖㽷病の雄平均 $2 . € 4 \pm 0.325 \mathrm{mg}$ で無処置の $\mathrm{f}_{3}$ ウサギより減少し, 統計的に有意の 差がある，また正常ウサギにアロキサン糖尿病を発症させたものより 2 倍の增加を示し，その值は正常值よ りも增加し統計的に有意の差がある. $\mathrm{f}_{4}$ ウサギのアロキサン糖尿病の雌平均 $2.42 \pm 0.182 \mathrm{mg}$ であり, 無処置 の $f_{4}$ ウサギにくらべて著しい減少をみる。しかし正常ウサギにアロキサン糖尿病を発症させたものの值の 2 倍を示している．またその值は正常值よりあ軽度增加しているが，統計的に有意の差はない．

尿中17-KS分劃 : 各世代とも無処置のものとくらべ全分劃が減少しているが， $\mathrm{f}_{1}, \mathrm{f}_{2}, \mathrm{f}_{3}$ の雄, 雌とも III 分劃ではその值が正常值に近く統計的に有意の差がない，また正常ウサギのアロキサン糖尿病を長期間持続 した場合之比较すると歴代両親実験的糖尿病子孫ウサギのアロキサン糖永病の場合になお VI, VII 分劃の增加 がみられ，統計的に有意の差がある.

3）実験的先天性糖尿病子孫ウサギの糖尿病非発症時にアロキサン糖尿病を発症させた場合

尿中17-KS 総量 : 48時間尿について $F_{1}$ ウサギのアロキサン糖尿病雄平均 $2.62 \pm 0.305 \mathrm{mg}$, 雌平均 $2.49 \pm$ $0.241 \mathrm{mg}$ でいずれも無処置のものにくらべて著しく減少している. $\mathrm{F}_{2}$ ウサギのアロキサン糖沓病雄平均 2.70 $\pm 0.263 \mathrm{mg}$ であるが，乙の $\mathrm{F}_{2}$ ウサギ雄の無処值動物は概当するむのがなく比較できないが $\mathrm{F}_{2}$ 雌， $\mathrm{F}_{1}, \mathrm{~F}_{3}$ 等 の無処置のものの値にくらへ減少している， $\mathrm{F}_{1}$ ウサギのアロキサン糖尿病の場合，無処置の $F_{1}$ ウサギ上統 計的に有意の差を示して低下している，その值は正常值より軽度增加を示すが統計的に有意の差はない．

尿中17-KS分劃： $\mathrm{F}_{1}$ ウサギのアロキサン糖尿病の場合無処置のものより全分劃の著しい減少を示すが，正 常ウサギのアロキサン糖尿病の場合および歴代両視実験的糖尿病子孫ウサギのアロキサン糖尿病の場合にく らべII, III, VI, VII分劃が明らかに増量している. 正常值とくらべると雌の分劃がやや減少し統計的に有 意の差がない以外一般に II, III, VI, VII 分劃が増肌し, $\mathrm{N}+\mathrm{V}$ 分劃は減少している， $\mathrm{F}_{2}$ 雄ウサギのアロキサ 
ン糖尿病の場合は無処置の概当するウサギがなく比較できないが $F_{1}$ と同じ傾向をむつている.

\section{第 3 章 実験的先天性糖尿病 Wistar 系シロネズミおよびこれらにアロキサン 糖尿病を発症させたさいの尿中17-KS総量ならびに分劃， FGS，ウロ ペプシンについて}

\section{第 1 節 研究材料}

\section{1）対照正常ネズミ}

対照正常ネズミとしては平均体重370g 位の成熟雄と 250 300g 位の雌の Wistar 系シロネズミの各20匹ず つを使用した。ささらに正常無処置成熟 Wistar 系シロネズミ雄，膗を交配し仔を生ませ雄，雌各15匹ずつを 得，乙れを飼育して成長時の钼察を行つた。

\section{2） 実験的先天性糖尿病子孫ネズミ}

岡本ら ${ }^{555) 56}$ とより作製された歴代雄アロキサン糖尿病 $F_{7}$ Wistar 系シロネズミで糖尿病を自然発症した雄

系図 2 実験的先天性糖尿病子孫 Wistar 系シロネズミ系図

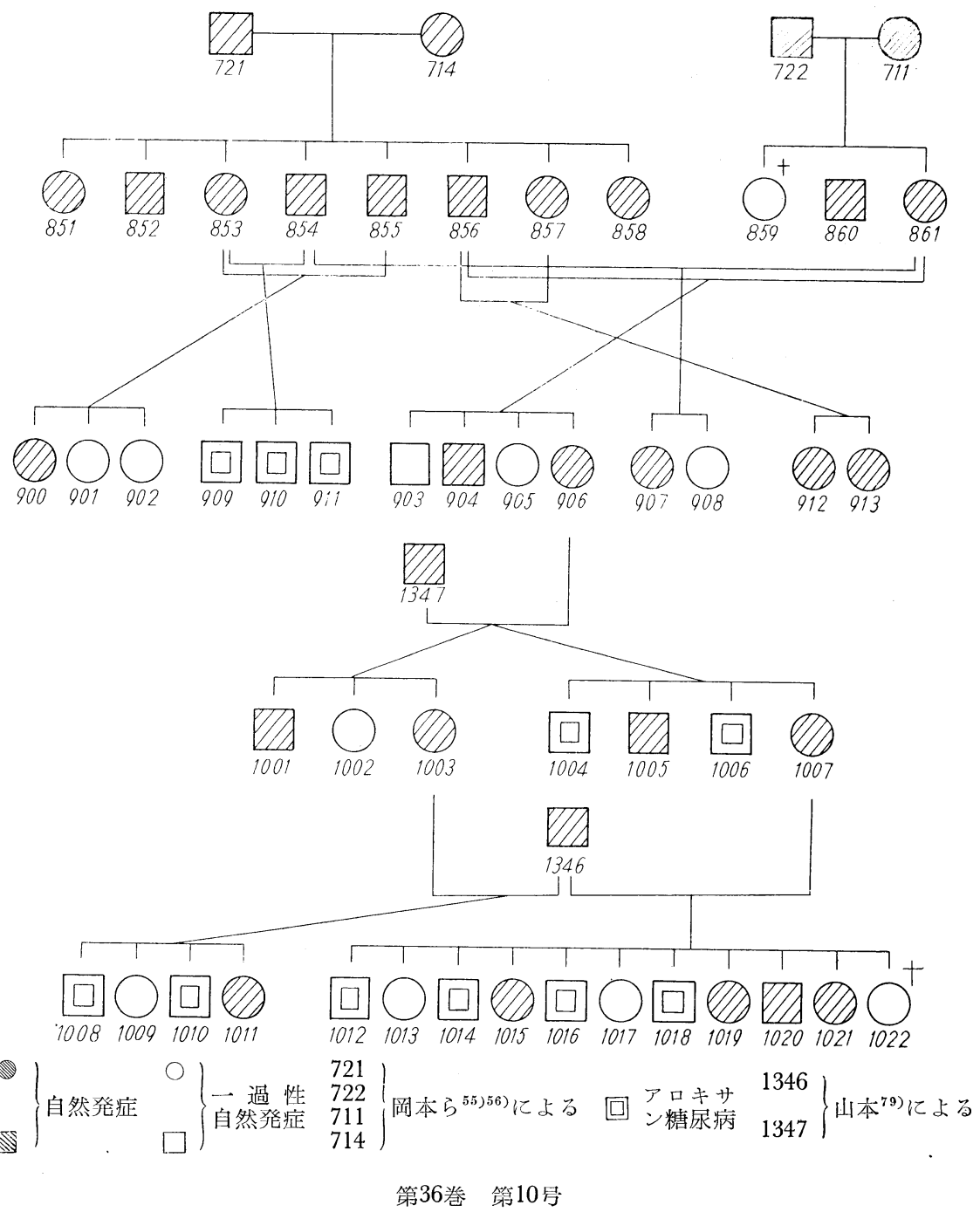


$721 ， 722$ ，雌711，714を用い 2 組の交配を行つて雄852，854，855，856，860の 5 匹と雌851，853，857,858, 859，861の 6 匹の合計11匹の仔を得，さらにその仔同志 5 組の交配により雄 $903 ， 904 ， 909 ， 910 ， 911 の 5$ 匹と雌 $900 ， 901 ， 902 ， 905 ， 906 ， 907 ， 908 ， 912 ， 913 の 9$ 匹の合計14匹の仔を得た. その雌906之山本 ${ }^{79}$ の 得た糖尿病自然発症雄ネズミ1357 (雄, 雌アロキサン糖尿病子孫 $\mathrm{F}_{5}$ 同志の交配による仔) とを交配して雄 1001 , 1004，1005，1006の 4 匹と雌1002，1003，1007の 3 匹の合計 7 匹の仔を得，その雌1003，1007と山本が1347 と同じようにして作製した糖尿病自然発症雄 1346 乙交配して雄 $1008 ， 1010 ， 1012 ， 1014 ， 1016 ， 1018 ， 1020$ の 7 匹と雌1009，1011，1013，1015，1017，1019，1021，1022の 8 匹の合計15匹の仔を得た。 乙れらの交配 は常に糖尿病持続 1 力月以上して行われた。 その系譜は系図 2 亿示した. 以上の子孫動物中早く死亡した 2 匹を除いた雄20匹と雌24匹を実験に供した。 なおこれらのうち雄903，904，909，910，911，1001，1004, 1006，1008，1010，1012，1014，1016，1018，1020の15匹之雌900，901，902，905，906，907，908，912， $913,1009,1011 ， 1013 ， 1015 ， 1017 ， 1019 ， 1021$ の 16 匹は離乳後より成熟までの間研究に供された. これ らの動物は全例生後 60 日前後より尿糖 $(+)$ （H）(尿糖判定基準は前のウサギのところで記述した）, 70日前 後より $(H) \sim(H H)$ を約10日〜40日間持続し，乙の間を糖尿病自然発症時期とし，以後は断続的に不定期の糖 尿をむらした。 またてれらのネズミの体重は成熟雄20匹平均 $390 \pm 36.0 \mathrm{~g}$ ，雌 24 匹平均 $272 \pm 25.5 \mathrm{~g}$ であつた。 これらの仔ネズミの生後30日の体重は対照ネズミにくらべて大きかつた.

\section{3）アロキサン糖尿病ネズミ}

正常成熟 Wistar 系シロネズミにアロキサン(Alloxan monohydrate 第一製薬製を使用した. 以下ネズミ は同様試薬を使用) $200 \mathrm{mg} / \mathrm{kg}$ を腹腔内に注射し，糖尿病を発症したものを供試した。 まず平均体重 $350 \mathrm{~g} の$ 雄ネズミ20匹にアロキサンを投与した。投与10日後には半数が死亡し, 残る10匹の平均体重は $270 \mathrm{~g}$ で, 30日

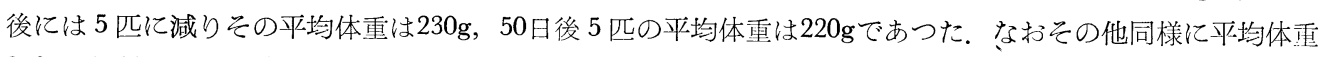
$350 \mathrm{~g}$ の雄20匹と平均体重 $270 \mathrm{~g}$ の雌20匹にアロキサン糖㽷病を発症させて 3 カ月以上の長期間糖尿病を持続し た平均体重 $210 \mathrm{~g}$ の雄 6 匹と平均体重 $185 \mathrm{~g}$ 雌 5 匹について測定を行つた.

4) 実験的先天性糖尿病子孫雄ネズミの糖尿病非発症時にアロキサン糖尿病を発症させた場合

2)に述べたネズミのうち生後 120 日以上経過して, しかも一過性の糖㽷病自然発症をみた後尿糖が(一) に なつた雄 $909,910 ， 911 ， 1004 ， 1006,1008 ， 1010 ， 1012 ， 1014 ， 1016 ， 1018 の 11$ 匹にアロキサンを150mg $\sim 180 \mathrm{mg} / \mathrm{kg}$ 腹腔内に注射しアロキサン糖尿病を発症させて実験に供した. 全例尿糖(HH)〜 (H⿻一川1)を持続した. これらのネズミの投与前平均体重は $375 \mathrm{~g}$ であつたが，投与 10 日後には $350 \mathrm{~g}, 30$ 日後には $320 \mathrm{~g}, 50$ 日後には $330 \mathrm{~g}$ で投与前より減少した。

以上のネズミは室温 $22 \pm 2{ }^{\circ} \mathrm{C} ，$ 湿度 $50 \pm 10 \%$ 環境を一定にした動物飼育室において金属製飼育籠を用い, 小麦, 小魚, 白色野菜の一定量を与えて飽育した。 仔ネズミは生後21日に母ネズミから離し，40日頃まで仔 ネズミ同志一緒に育て，その後は同性同志 2 匹ずつに分けて飼育した. 各ネズミは生後30日より体重測定を 開始し，10日目每に測定を行つた．採尿時にはネズミの健康状態に注意し，尿に食物残渣，糞等の入ら双よ う二重網底の漏斗付き金属性採尿籠を用い，その 1 つあてに成熟後は 1 匹ずつ，仔ネズ之は 2,3 匹ずつ一 緒に入れた. 飲料水が落ちないように吸水管のガラス孔の大きさに注意した. 自然の状態で採尿を行うため ネズミを一定時日採尿籠で飼育し，新しい環境になれてから採尿した．㽷中ホルモンの変性を防ぐため $24 \mu_{\text {寺 }}$ 間採尿後ただちに氷室に入れ，24時間，48㭙間または 4 日間採尿終了後ただちに測定操作を行つた.

\section{第 2 節 研究方法}

\section{1）ネズミ尿中17·KS総量測定法}

万法は48時間尿につきウサギの場合と同様三宅，扇谷の才汢 ${ }^{39}$ に從い Drekter 法:17)に準じて粗製尿エキス を作つた. またネズミ尿のZimmermann 反応を与える呈色干渉物質の除去 ${ }^{23)(41)}$ 亿注意して Pincus の MicroGirards法 ${ }^{60}$ を用い非ケトン分劃を除き，そのナトン分劃について Pearson 法 $^{59}$ に從つて Zimmermann 反応 ${ }^{50)}$ 81)を行い日立分光光度計 EPU-2型を用い530m $\mu$ で比色定量した.

\section{2）ネズミ尿中17-KS分劃測定法}


1758

歴代実験的糖尿病子孫ウサギ执よび Wistar 系シロネズミの尿中ケトステロイド， ウロペプシンの排泄状態ならびにアロキサン投与による影響について（石崎）

ネズミは尿量が少く，粘液㥞物質やZ Zimmermann 反応を与える呈色干渉物質が多く，そのわりに17KS 排泄量が少いため従来は17-KS分劃の測定は行 われていない.

私は実験㲜物の採尿にとくに注意し数匹分尿を 24 時間毎に氷室保存 4 日間採尿後，前記の方法を用 いてケトン分劃在得, Pond ${ }^{(1)}$, Edwards ${ }^{19)}$, 大野 ${ }^{67)}$ の方法により Liquid Column Partition Chromatography を行いウサギの場合之同様に数匹分 4 日間 尿について測定を行い，1匹48時間值を算定した。

3) ネズミの尿中 Formaldehydogenic steroid(FGS) 測定法

Bush ら 7)8)928)29) は副腎皮質から分泌されるグル ココルチコイドは動物により差異があり，ネズミで はコルチコステロンが多く，ハイドロコーチゾンは 少いかまたはないと報告した。 ネズミのコルチコイ ドは17-KS測定法のみでは不充分であり，17-OHCS 測定法 ${ }^{63)}$ では測定できない年969)。 それで私は Burstein ${ }^{6)}$ がモルモットで行つた Daughaday 変法にも とづき村中 ${ }^{42}{ }^{43}$ がネズミで行つた方法を参考にして FGS の測定を行つたのである。その方法は次のよ うである。

24時間尿に塩化ナトリウムを飽和沈澱するまで加 えて後 $50 \%$ 硫酸でpH1.0亿調整し，クロロホルム 20 $\mathrm{cc}$ と $10 \mathrm{cc}$ で 2 回抽出し，そのクロロホルムを”0.2 容 の $1 / 10 \mathrm{~N}$ 苛性ソーダで 2 回, 蒸溜水で 1 回洗滌し, その洗滌液屯各回クロロホルム10ccで逆抽出し, 全 クロロホルムを硫酸ソーダで脱水，濾過し $40^{\circ} \mathrm{C} て ゙$ 減 圧乾固する。乾燥残渣はベンゼン1ccで溶かし，ピペ ットで10cc共栓付遠心管にうつし, 容器を $1 \mathrm{cc}$ と 0.5 $\operatorname{cc} の$ ベンゼンで洗い同様にうつし，蒝溜水 $5 \mathrm{cc}$ 加 えて，強振，遠心分離するとコルチコイドは水分劃 にうつる．水分劃の $4 \mathrm{cc}$ を型フラスコにとり（盲 検として蒸溜水 $4 \mathrm{cc}$ 用意し以後同様の操作を行 う). $0.03 \mathrm{M}$ 過沃度酸力リの0.025M硫酸溶液 $0.5 \mathrm{cc}$ を 加え室温に放置，45分後 $3 \%$ 塩化第一錫塩酸溶液 (毎回新調) $0.5 \mathrm{cc}$ を加えて酸化を停止する。蒸溜水 $0.5 \mathrm{cc} ， 3 \mathrm{M}$ 硫酸 $0.5 \mathrm{cc}$ を加えて全量を $6 \mathrm{cc}$ とし，15 $\mathrm{cc}$ 目盛共栓付遠心管に $4 \mathrm{cc}$ のロモトロープ酸硫酸 溶液（クロモトロープ酸 (1,8-Dihydroxynaphthalene sulfonic acid 住友化学製) $150 \mathrm{mg}$ を前記の 3 $\%$ 塩化第一錫塩酸溶液 2 ccに溶解し，泠却しながら 濃硫酸を加え全量を50ccにする。毎回新調) 中へ

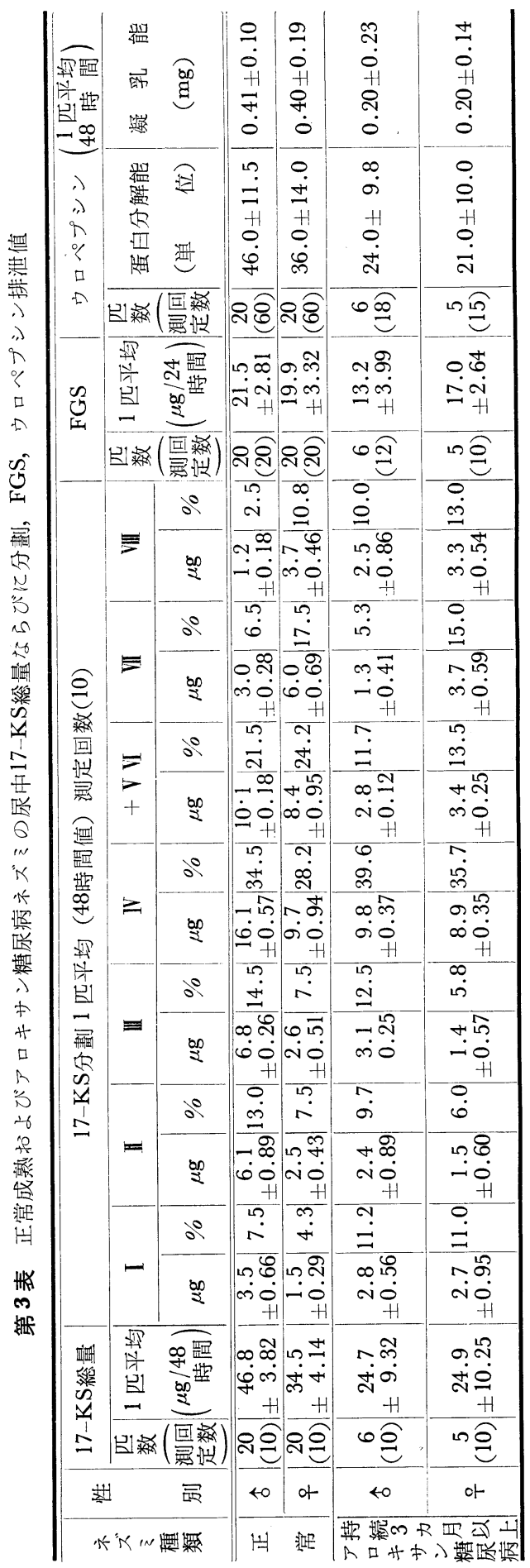
Hadd $^{26)}$ の蒸溜装置を用いてガス小火焰で全量 8 ccまで蒸溜する，遠心管に共栓をし30分沸騰浴後室温で泠却， 
第 4 表 正常ネズミ生後日数別尿中17-KS総量, FGS，ウロペプシン 排泄值扢よび体重（今 우15匹平均值）

\begin{tabular}{|c|c|c|c|c|c|c|c|c|c|c|}
\hline \multirow{3}{*}{$\begin{array}{l}\text { 生 } \\
\text { 後 } \\
\text { 日 } \\
\text { 数 }\end{array}$} & \multirow{3}{*}{$\begin{array}{l}\text { 性 } \\
\text { 別 }\end{array}$} & \multirow{3}{*}{$\begin{array}{c}\text { 体 重 } \\
(\mathrm{g})\end{array}$} & \multirow{2}{*}{\multicolumn{2}{|c|}{ 17-KS 総量 }} & \multirow{2}{*}{\multicolumn{2}{|c|}{ FGS }} & \multicolumn{4}{|c|}{ ウロペプシン（48時間） } \\
\hline & & & & & & & \multicolumn{2}{|c|}{ 蛋白分解能 } & \multicolumn{2}{|c|}{ 凝 乳 能 } \\
\hline & & & $\begin{array}{l}\text { 測定 } \\
\text { 回数 }\end{array}$ & ( $\mu \mathrm{g} / 48$ 時間) & 測定 & ( $\mu \mathrm{g} / 24$ 時間) & $\begin{array}{l}\text { 測定 } \\
\text { 回数 }\end{array}$ & （単 位） & $\begin{array}{l}\text { 測定 } \\
\text { 国数 }\end{array}$ & $(\mathrm{mg})$ \\
\hline \multirow{2}{*}{30} & $\hat{o}$ & $46 \pm 5.5$ & \multirow[t]{2}{*}{3} & \multirow{2}{*}{$\begin{array}{c}14 \\
(8 \sim 9)\end{array}$} & & \multirow{2}{*}{$\begin{array}{c}4.9 \\
2.7 \sim 6.1\end{array}$} & 6 & $13 \pm 1.2$ & 4 & 0.10 \\
\hline & 우 & $45 \pm 6.3$ & & & & & 4 & $10 \pm 1.3$ & 5 & $0.09 \pm 0.262$ \\
\hline \multirow{2}{*}{40} & $\hat{\delta}$ & $84 \pm 6.1$ & \multirow{2}{*}{3} & & 3 & $\begin{array}{c}5.8 \\
3.4 \sim 6.6 \\
\end{array}$ & 7 & $24 \pm 1.6$ & 7 & $0.20 \pm 0.013$ \\
\hline & 우 & $85 \pm 4.6$ & & $15 \sim 26$ & 3 & $\begin{array}{c}5.7 \\
4.9 \sim 6.9 \\
\end{array}$ & 6 & $18 \pm 1.5$ & 8 & $0.17 \pm 0.013$ \\
\hline \multirow[t]{2}{*}{50} & $\hat{o}$ & $107 \pm 5.8$ & 4 & $\begin{array}{c}29 \\
24 \sim 35\end{array}$ & 15 & $12.0 \pm 2.86$ & & & & \\
\hline & 우 & $100 \pm 5.0$ & 4 & $\begin{array}{c}26 \\
20 \sim 28\end{array}$ & 15 & $15.2 \pm 4.54$ & & & & \\
\hline \multirow[t]{2}{*}{60} & 令 & $123 \pm 8.3$ & 4 & $\begin{array}{c}34 \\
24 \sim 52\end{array}$ & 15 & $13.2 \pm 2.83$ & 8 & $28 \pm 1.1$ & 9 & $0.26 \pm 0.014$ \\
\hline & 우 & $115 \pm 3.0$ & 4 & $21 \sim 40$ & 15 & $12.6 \pm 2.82$ & 10 & $21 \pm 1.2$ & 9 & $0.20 \pm 0.021$ \\
\hline \multirow[t]{2}{*}{70} & $\hat{\delta}$ & $185 \pm 14.0$ & 4 & $\begin{array}{c}42 \\
32 \sim 52\end{array}$ & 15 & $15.4 \pm 2.01$ & 10 & $35 \pm 2.1$ & 10 & $0.30 \pm 0.031$ \\
\hline & 우 & $160 \pm 5.7$ & 4 & $\begin{array}{c}31 \\
26 \sim 45 \\
\end{array}$ & 15 & $13.6 \pm 2.76$ & 10 & $30 \pm 1.4$ & 10 & $0.34 \pm 0.013$ \\
\hline \multirow[t]{2}{*}{80} & $\hat{\delta}$ & $200 \pm 11.1$ & 4 & $\begin{array}{c}45 \\
41 \sim 58\end{array}$ & 15 & $19.6 \pm 2.08$ & 15 & $39 \pm 2.2$ & 15 & $0.42 \pm 0.011$ \\
\hline & 우 & $180 \pm 5.7$ & 4 & $\begin{array}{c}32 \\
28 \sim 40 \\
\end{array}$ & 15 & $14.3 \pm 2.76$ & 15 & $36 \pm 2.6$ & 15 & $0.44 \pm 0.025$ \\
\hline \multirow[t]{2}{*}{90} & $\hat{\delta}$ & $230 \pm 16.0$ & 4 & $\begin{array}{c}43 \\
32 \sim 58 \\
\end{array}$ & 15 & $18.6 \pm 3.98$ & 10 & $44 \pm 1.3$ & 8 & $0.40 \pm 0.021$ \\
\hline & 우 & $195 \pm 10.0$ & 4 & $\begin{array}{c}32 \\
26 \sim 41 \\
\end{array}$ & 15 & $18.2 \pm 2.29$ & 10 & $41 \pm 3.2$ & 11 & $0.39 \pm 0.027$ \\
\hline \multirow[t]{2}{*}{100} & $\hat{\delta}$ & $255 \pm 11.7$ & 4 & $\begin{array}{c}47 \\
28 \sim 50\end{array}$ & 15 & $20.2 \pm 4 \cdot 54$ & 20 & $46 \pm 2.4$ & 20 & $0.41 \pm 0.030$ \\
\hline & 우 & $205 \pm 8.4$ & 4 & $\begin{array}{c}35 \\
23 \sim 42 \\
\end{array}$ & 15 & $19.8 \pm 4.12$ & 20 & $40 \pm 1.6$ & 20 & $0.36 \pm 0.023$ \\
\hline
\end{tabular}

日立分光光度計 EPU-2型を用い510，570，630m $\mu$ で30分以内に旨検に対してよみ，最高吸光度が $570 \mathrm{~m} \mu$ で あることを確かめてコルチコステロンで作成した標準曲線にあわせて $\mu \mathrm{g}$ 求め 1 日の尿量より算定した。 回 収率は84〜91\%であつた，測定值と尿量，体重に一定の関係は認められなかつた，過沃度酸はアルコール基 を有する化合物に反応してフオルムアルデヒドを発生する。をして私は糖㽷病の尿について測定を行う必要 があるので，糖の干渉について検討した。 その結果，私の行つた方法ではブドウ糖 $5 \%$ 以下の添加では活と んど干渉しないととを知つた.

\section{4) ネズミ尿中ウロペプシン測定法}

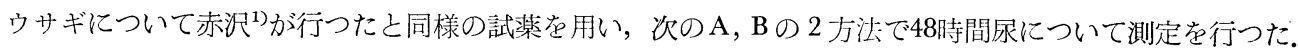

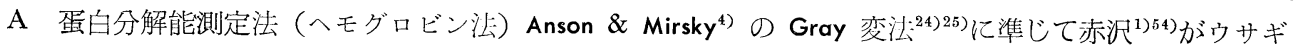
について行つた方法に従つた.

B 凝乳能測定法

West の方法 ${ }^{76}$ にもとづき福牛ら ${ }^{21)}$ が行つたスキ人ミルクを用いパプシンで牛乳在凝固させる能力を応用 して測定した.

\section{5) 統計学的検定}

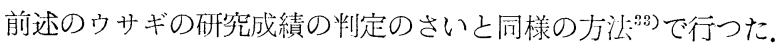




\section{第 3 節 研究成績 \\ 第 1 項 無処置群の尿中 17-KS 総量ならびに分劃, FGS，ウロペプシン}

1) 対照正常ネズミ

尿中17-KS総量：正常成熟ネズミの測定結果は第 3 表に示した。 48 時間尿における雄20匹平均值は $46.8 \pm 3.82 \mu \mathrm{g}$, 雌 20 匹の平均值は $34.5 \pm 4.14 \mu \mathrm{g}$ であ つた。成長時の測定結果は第 4 表, 第 6 図に示した 通りである。すなわち雄，雌15匹ずつの48時間尿で 測定し．关の平均值をみるに生後50日で性差がるら れ，80日で成熟時の值を示す。

尿中17-KS分劃：正常ネズミで得た測定結果は第 3 表にみるようにクロマトグラムにおいて雄，雙と あ 8 分劃に分れ, 各分劃のクロマトグラム上の位置

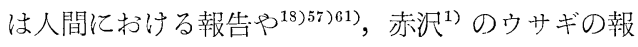

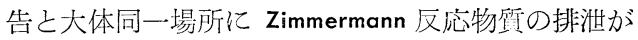
ある. 正常ネズミ48時間原における各分劃の百分率， 絶体值は V + V 分劃が雄は $34.5 \%, 16.1 \pm 0.57 \mu \mathrm{g}$, 雌 $28.2 \% ， 9.7 \pm 0.94 \mu \mathrm{g}$ で，雄が高く, 㸪分劃では 雄は $6.5 \%, 3.0 \pm 0.28 \mu \mathrm{g}$, 雌 $17.5 \%, 6.0 \pm 0.69 \mu \mathrm{g}$ で雌が高い。

尿中FGS：正常成熟ネズミの24時間尿について雄 20 匹平均值 $21.5 \pm 2.81 \mu \mathrm{g}$, 雌 20 匹平均值 $19.9 \pm 3.32$ $\mu \mathrm{g}$ で雄，雌間に統計的に有意の养はない，また生後 30 日より成長時の測定結果忷第 4 表, 第 6 図に示し た通り成長にとむないぜんじ增加し80日頃には成熟 時の值を示す。

尿中ウロペプシン：正常成熟ネズミ48時間尿につ いて雄，雌20匹ずつの平均值は蛋白分解能法では雄 $46.0 \pm 11.5$ 単位，傩 $36.0 \pm 14.0$ 単位て雄，雌間に有 意の差はない，凝乳能法では雄 $0.41 \pm 0.10 \mathrm{mg}$, 倠 $0.40 \pm 0.19 \mathrm{mg}$ でやはり両者の間に有意の差はない. 成長期の測定結果は第 4 表に示した通り生後 80 日で 成熟時の値を示している。

2) 実験的先天性糖尿病子孫ネズミ

尿中17-KS総量 : 実験的先天性:糖尿病子孫成熟六ズ 々の測定結果は第 5 表，第 3 図に示した。48恃間尿 そついて雄18匹の平均值は $65.4 \pm 11.87 \mu \mathrm{g}$, 雌20匹 の平均値は $54.0 \pm 10.54 \mu \mathrm{g}$ で対照正常ネズミにくら べて增加しており，統計的に有意の颜がある，成長 時の測定結果は第 6 表，第 6 図に示した通りで，糖 尿病自然発症前の幼若未発症時期の生後 50 日では，48時間尿について雄 $47.2 \pm 7.18 \mu \mathrm{g}$, 雌 $43.6 \pm 9.26 \mu \mathrm{g}$ で 対照正常ネズミより高值を示し，成長するに従つて増加している，自然発症のみられる70日前後では正常值

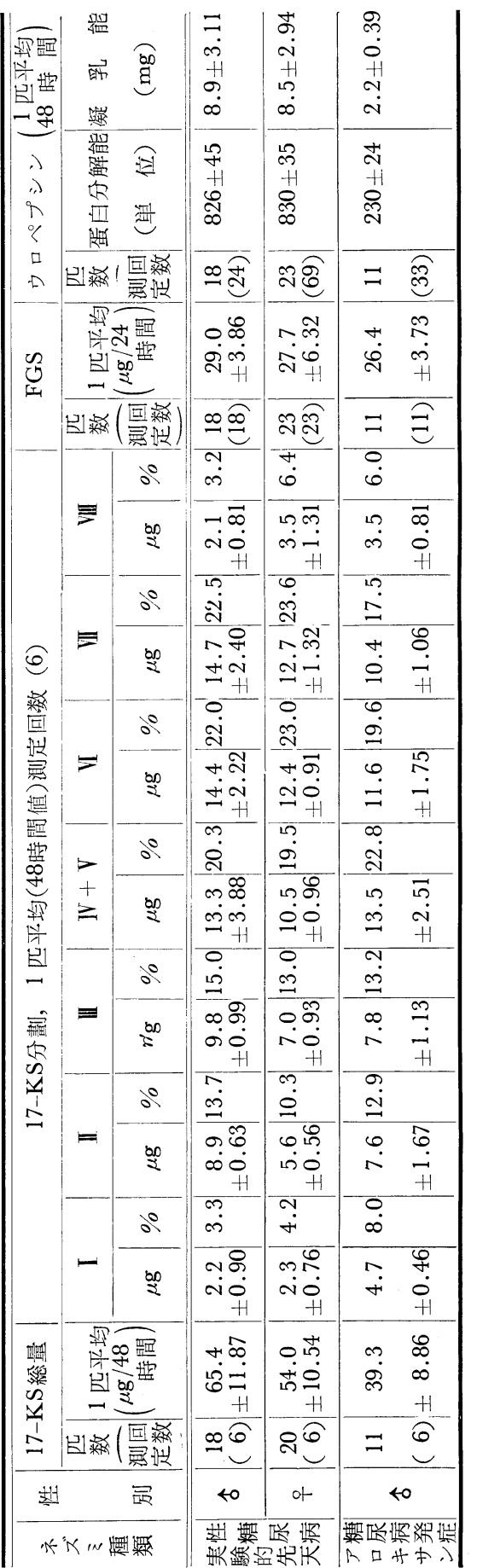


第 6 表 実験的先天性糖尿病ネズミ生後日数別尿中17-KS総量, FGS， ウロペプシン排泄值打よび体重（古15匹，早16匹平均値）

\begin{tabular}{|c|c|c|c|c|c|c|c|c|}
\hline \multirow{2}{*}{$\begin{array}{l}\text { 生後 } \\
\text { 日数 }\end{array}$} & \multirow{2}{*}{$\begin{array}{l}\text { 性 } \\
\text { 別 }\end{array}$} & \multirow{2}{*}{${ }^{\text {体 }}(\mathrm{g})^{\text {重 }}$} & \multicolumn{2}{|c|}{ 17-KS総量 } & \multicolumn{2}{|r|}{ FGS } & \multicolumn{2}{|c|}{$\begin{array}{c}\text { ウ口ペプシ ン } \\
\text { (48時間) }\end{array}$} \\
\hline & & & $\begin{array}{l}\text { 測定 } \\
\text { 回数 }\end{array}$ & ( $\mu \mathrm{g} / 48$ 時間測) & $\begin{array}{l}\text { 測定 } \\
\text { 回数 }\end{array}$ & （ $\mu \mathrm{g} / 24$ 時間） & $\begin{array}{l}\text { 測定 } \\
\text { 回数 }\end{array}$ & $\times$ 倍 数 \\
\hline \multirow[t]{2}{*}{30} & $\hat{o}$ & $71 \pm 14.3$ & & & \multirow{2}{*}{6} & \multirow{2}{*}{$8.4 \pm 2.63$} & 4 & $\begin{array}{c}\times 3 \\
\times 2 \sim 5\end{array}$ \\
\hline & 우 & $66 \pm 13.7$ & & & & & 5 & $\begin{array}{r}\times 2 \\
\times 2 \sim 3 \\
\end{array}$ \\
\hline \multirow[t]{2}{*}{40} & $\hat{\delta}$ & $103 \pm 27.4$ & & & 6 & $10.7 \pm 4.24$ & 6 & $\begin{array}{c}\times 12 \\
\times 3 \sim 16 \\
\end{array}$ \\
\hline & 우 & $99 \pm 13.8$ & & & 6 & $9.7 \pm 2.89$ & 6 & $\begin{array}{r}\times 16 \\
\times 9 \sim 19 \\
\end{array}$ \\
\hline \multirow[t]{2}{*}{50} & $\hat{\delta}$ & $154 \pm 28.3$ & 6 & $47.2 \pm 7.18$ & 15 & $16.6 \pm 3.64$ & & \\
\hline & 우 & $146 \pm 21.2$ & 6 & $43.6 \pm 9.26$ & 16 & $13.9 \pm 3.32$ & & \\
\hline \multirow[t]{2}{*}{60} & $\hat{\delta}$ & $208 \pm 32.2$ & 6 & $50.1 \pm 11.97$ & 15 & $17.2 \pm 3.51$ & 10 & $\begin{aligned} & \times 21 \\
& \times 18 \sim 24 \\
&\end{aligned}$ \\
\hline & 우 & $181 \pm 14.1$ & 6 & $45.8 \pm 5.96$ & 16 & $22.9 \pm 3.56$ & 10 & $\begin{array}{c}\times 19 \\
\times 14 \sim 22\end{array}$ \\
\hline \multirow[t]{2}{*}{70} & $\hat{\delta}$ & $252 \pm 39.6$ & 6 & $57.1 \pm 4.84$ & 15 & $33.3 \pm 3.61$ & 15 & $\begin{array}{c}\times 20 \\
\times 14 \sim 23 \\
\end{array}$ \\
\hline & 우 & $214 \pm 24.8$ & 6 & $47.6 \pm 5.41$ & 16 & $24.7 \pm 3.94$ & 15 & $\begin{array}{c}\times 18 \\
\times 14 \sim 20 \\
\end{array}$ \\
\hline \multirow[t]{2}{*}{80} & $\hat{o}$ & $275 \pm 33.2$ & 6 & $59.0 \pm 3.24$ & 15 & $34.9 \pm 3.78$ & 14 & $\begin{array}{c}\times 20 \\
\times 16 \sim 23 \\
\end{array}$ \\
\hline & 우 & $231 \pm 22.6$ & 6 & $51.0 \pm 6.76$ & 16 & $32.8 \pm 3.00$ & 15 & $\begin{array}{c}\times 22 \\
\times 19 \sim 24 \\
\end{array}$ \\
\hline \multirow[t]{2}{*}{90} & $\hat{o}$ & $315 \pm 31.1$ & 6 & $65.7 \pm 6.47$ & 15 & $29.6 \pm 3.23$ & 15 & $\begin{array}{l}\times 19 \\
\times 15 \sim 24 \\
\end{array}$ \\
\hline & 우 & $251 \pm 22.7$ & 6 & $54.0 \pm 7.89$ & 16 & $31.3 \pm 5.94$ & 15 & $\begin{array}{c}\times 20 \\
\times 18 \sim 23 \\
\end{array}$ \\
\hline \multirow[t]{2}{*}{100} & $\hat{\delta}$ & $327 \pm 32.5$ & 6 & $65.7 \pm 4.64$ & 15 & $30.2 \pm 4.47$ & 20 & $\begin{array}{c}\times 21 \\
\times 19 \sim 23 \\
\end{array}$ \\
\hline & 우 & $257 \pm 21.7$ & 6 & $57.4 \pm 6.51$ & 16 & $27.4 \pm 6.56$ & 20 & $\begin{array}{c}\times 23 \\
\times 20 \sim 24\end{array}$ \\
\hline
\end{tabular}

\section{の1.4倍を示す。}

尿中17-KS分劃 : 第 5 表, 第 4 図に示す通り正常ネズミにくらべて雄, 雌とも II，III, VI, 壮分劃が増加 している，四分劃の増加は雄，雌とも著しい，成長時の測定結果は第 7 表，第 5 図に示すようにすでに生後 50〜60日で II， III，VI，VIII分劃の增加がみられた。

尿中 FGS : 雄18匹の 24 時間尿についての平均值 $29.0 \pm 3.86 \mu \mathrm{g}$, 雌 23 匹の平均值は $27.7 \pm 6.32 \mu \mathrm{g}$ で正常ネ ズミにくらべて增加しており，統計的に有意の差がある。しかし雄，雌間に有意の差はない，成長時の測定 結果は第 6 図にみるように生後 30 日よりすでに正常ネズミより高く，70日から80日頃に最高值を示し，その 後も高い値を持続している。

尿中ウロペプシン：雄18匹，雌23匹の48時間尿についての平均值は蛋白分解能法では雄”826士45単位，雌 $830 \pm 35$ 単位, 凝乳能法では雄 $8.9 \pm 3.11 \mathrm{mg}$, 雌 $8.5 \pm 2.94 \mathrm{mg}$ でやはり雄, 雌間に統計的に差はない，両方 法によつて得た測定結果はいずれも正常值にくらべて明らかに増加している。成長時の測定結果は離乳時よ り正常ネズミの 2 ～倍の值を示し，60日頃から急激な増加を来し以後高值を持続している．乙の成脣時の 測定結果は17-KS総量, FGS 值等之ほぼ平行している.

\section{第 2 項 アロキサン投与群の尿中17-KS総量ならびに分劃, FGS，ウロペプシン}

1)正常ネズミにアロキサン糖尿病を発症させた場合

尿中17-KS総量 : 正常成熟雄ネズミにアロキサン糖尿病を発症させたさいの測定結果は第 8 表に示したよ 
第 3 図正常ネズミと実験的先天性糖尿病ネズミ执よびとれにアロキサン

糖尿病を発症させたさいの尿中17-KS総量, FGS

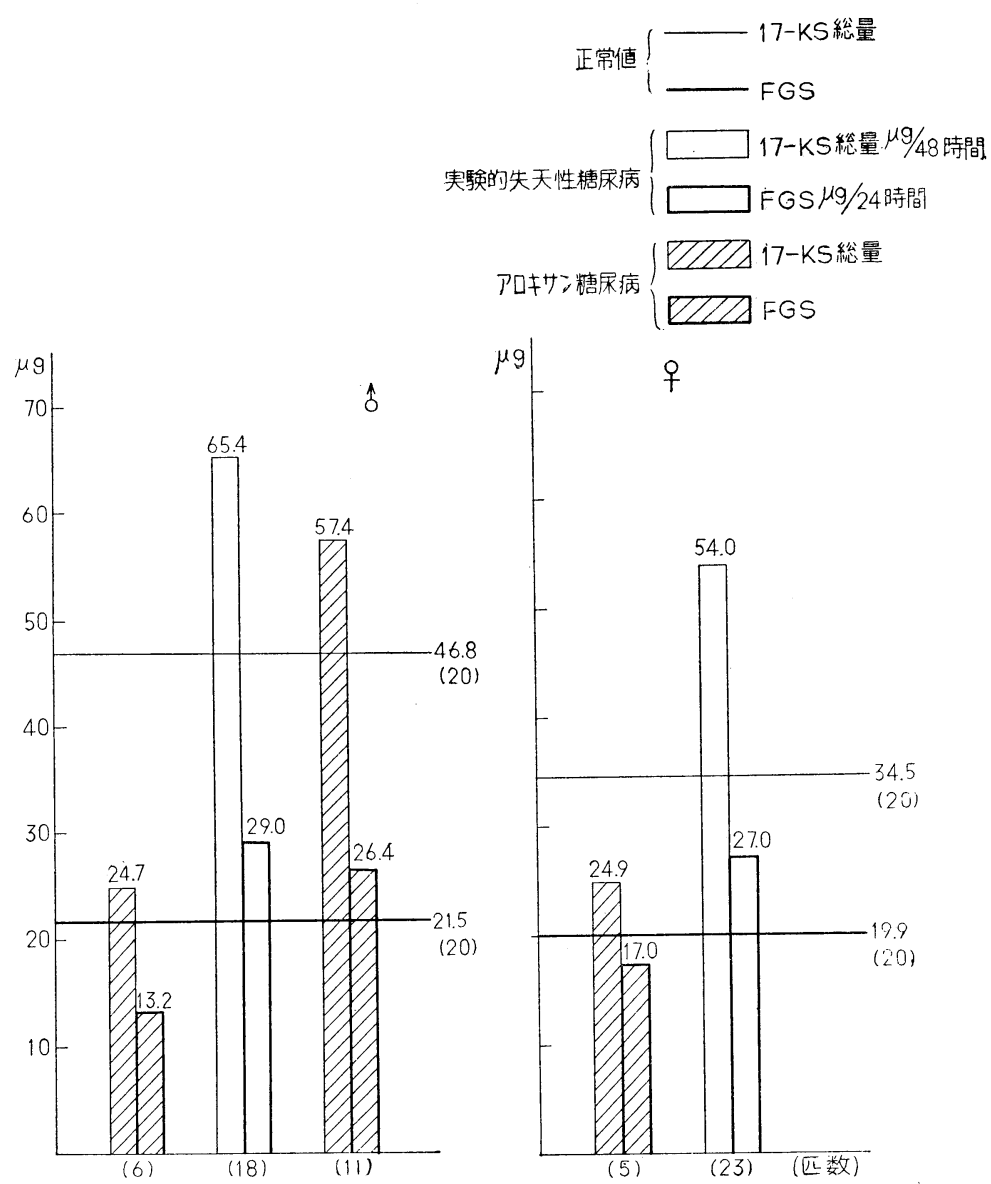

うに投与 10 日後に著増し，30日後には投与前值を示し，50日後には正常值以下に低下し統計的に有意の差が ある。第 3 表，第 3 図に 3 カ月以上アロキサン糖㽷病を持続した雄 6 匹，雌 5 匹の測定結果を示した. 48時 間尿についての平均值は雄 $24.7 \pm 9.32 \mu \mathrm{g}$, 雄 $24.9 \pm 10.25 \mu \mathrm{g}$ で正常值以下に減少している.

尿中17-KS分劃：第 7 図に示すようにアロキサン投与10日後にII，正分劃の増加がみられ，50日後には II， III，VI，W分劃が減少している。第 4 図に示すようにさらに 3 力月以上糖尿病を持続したものは全分劃の減 少がみられる。

㽷中 FGS：アロキサン投与10日後に増加し，30日後もなお投与前值より高く，50日後には投与前値と統 訃的に有意の差がなく減少を示す。さらに 3 カ月以上の長期間アロキサン糖尿病を持続した雄 6 匹，雌 5 匹

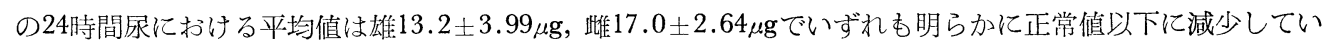
る.

尿中ウロペプシン：両測定法でアロキサン投与10日後に一過性の増加を示し，50日後には著しく減少し正 常值以下になる。なお 3 力月以上長期間アロキサン糖尿病を持続するむのの雄，雌とも正常值の $1 / 2$ の值を 示している.

2）実験的先天性糖尿病子孫ネズミの糖尿病非発症時にアロキサン糖尿病を発症させた場合

尿中17-KS総量 : 実験的先天性糖尿病雄ネズミ11匹にアロキサン糖尿病を発症させたさいの測定結果は第 
第 4 図 正常ネズミと実験的先天性糖尿病ネズミ扣よびこれに アロキサン糖尿病亚症させた際の尿中17-KS分劃
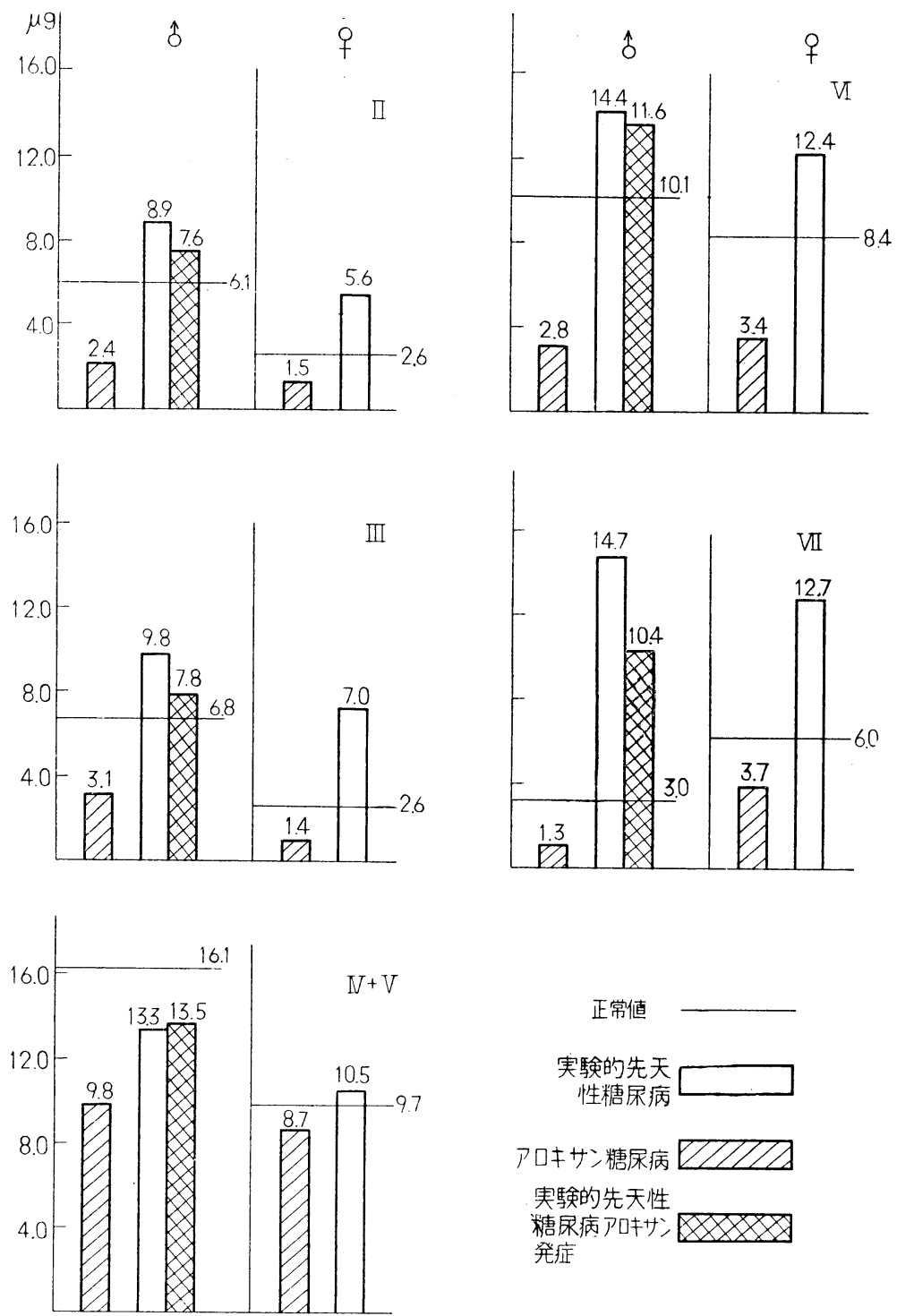

5 表，第 8 表に示した通りである。第 5 表のように投与10日後に増加を示し，30日後に投与前值となり，50 日後には $57.4 \pm 9.97 \mu \mathrm{g} / 48$ 時間でさきの無処犆の場合より減少し統計的に有意の差がある．なお正常值にく らべて高值を示す.

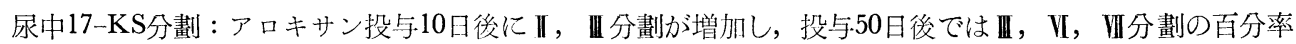
が投与前值より減少し，絶体值は $I ， \mathbb{I I} ， \mathrm{IV}+\mathrm{V}, \mathrm{V}, \mathrm{VI} の$ 各分劃で減少がみられるがやはり正常值より高 ().

尿中 FGS : アロキサン投与10日後に投与前の 2 倍に増加し，30日後には投与前值になり統許的に有意の 差はない，50日後では明らかに減少を示すが正常值より高い值で統計的に有意の差がある。 
第 5 図 正常ネズミ打よび実験的先天性糖尿病ネズミ生後日数別尿中17-KS分劃
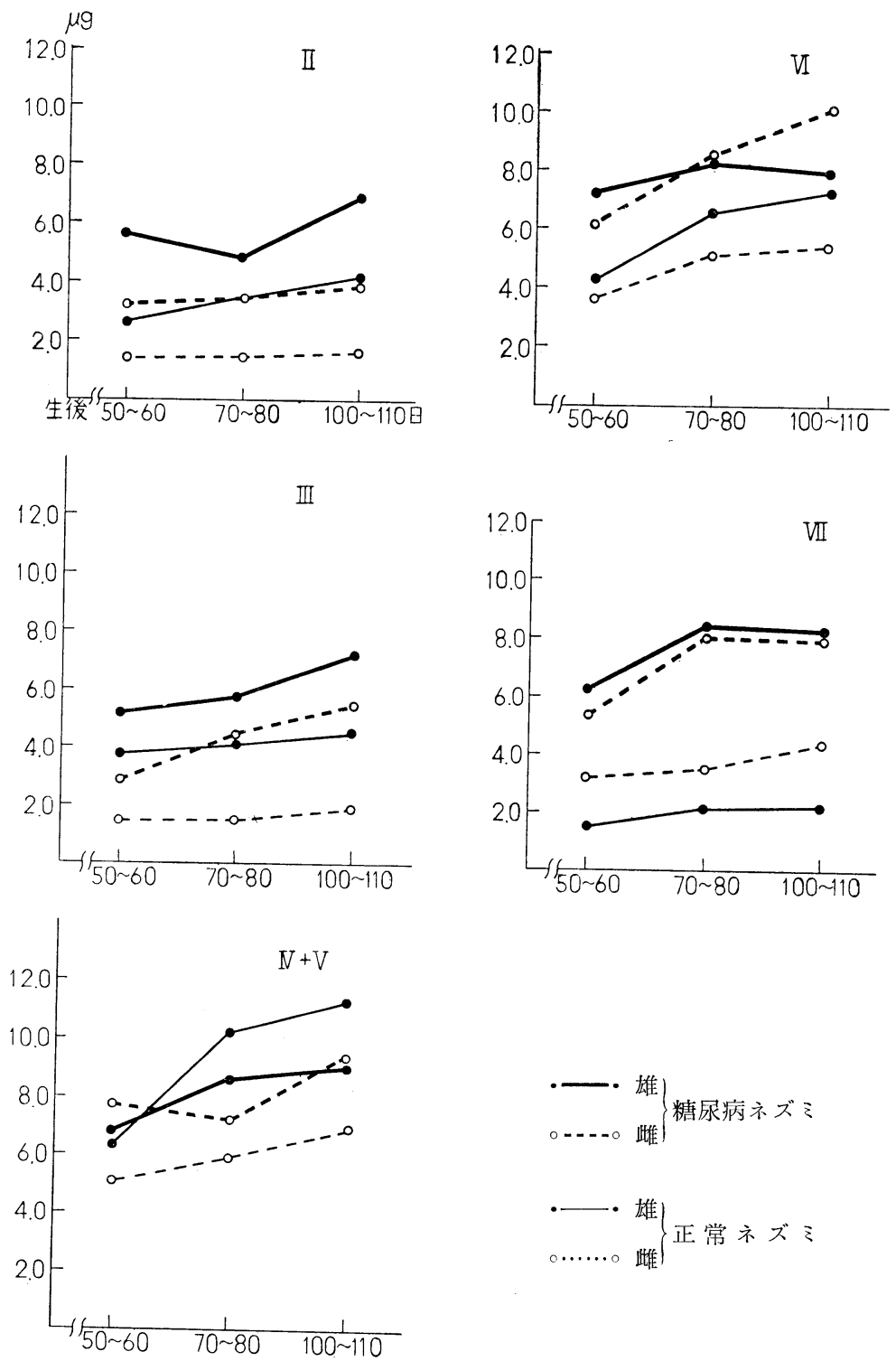

尿中ウロペプシン：アロキサン投与10日後には同様に一過性の増加がみられ，その後減少してゆくが投与 50日後では正常值よりなお高く，しかも投与前值より減少している.

第 4 章 考

按

岡本らが得た歴代実験的糖尿病子孫動物には膵ラ氏島の発育障碍が認められ，累代的にこの障碍の程度が 増強されてつい糖㽷病の自然発症をみる。としてとれらの動物では脳下垂体にも一定の变化がみとめられ るが，ことに副腎皮質において特長ある機能六進の組織像が報告 ${ }^{66}$ されている。 またてれらウサギの尿中

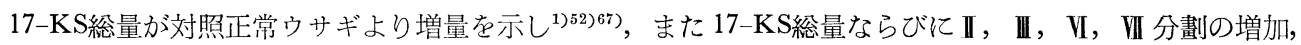


第 7 表 正常ネズミ扎よび実験的先天性糖尿病ネズミ生後日数別尿中17-KS総量ならびに分劃

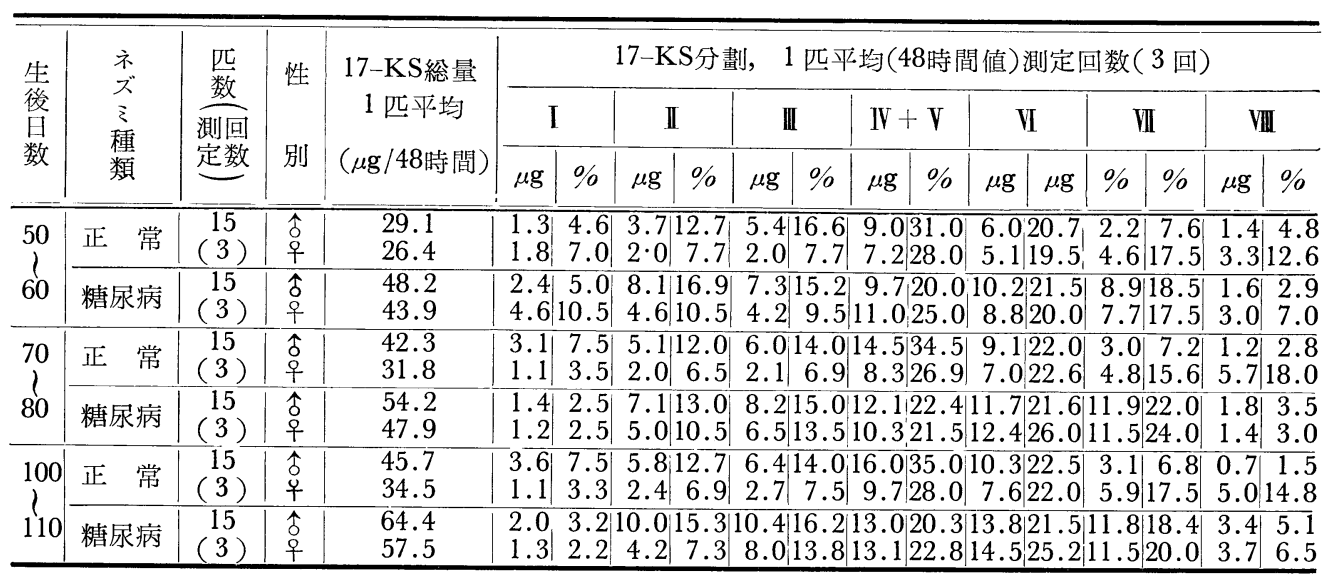

第 6 図 正常ネズミおよび実験的先天性糖尿病ネズミ生後日数別尿中17-KS総量,

FGS，ウロペプシン排泄值扔よび体重
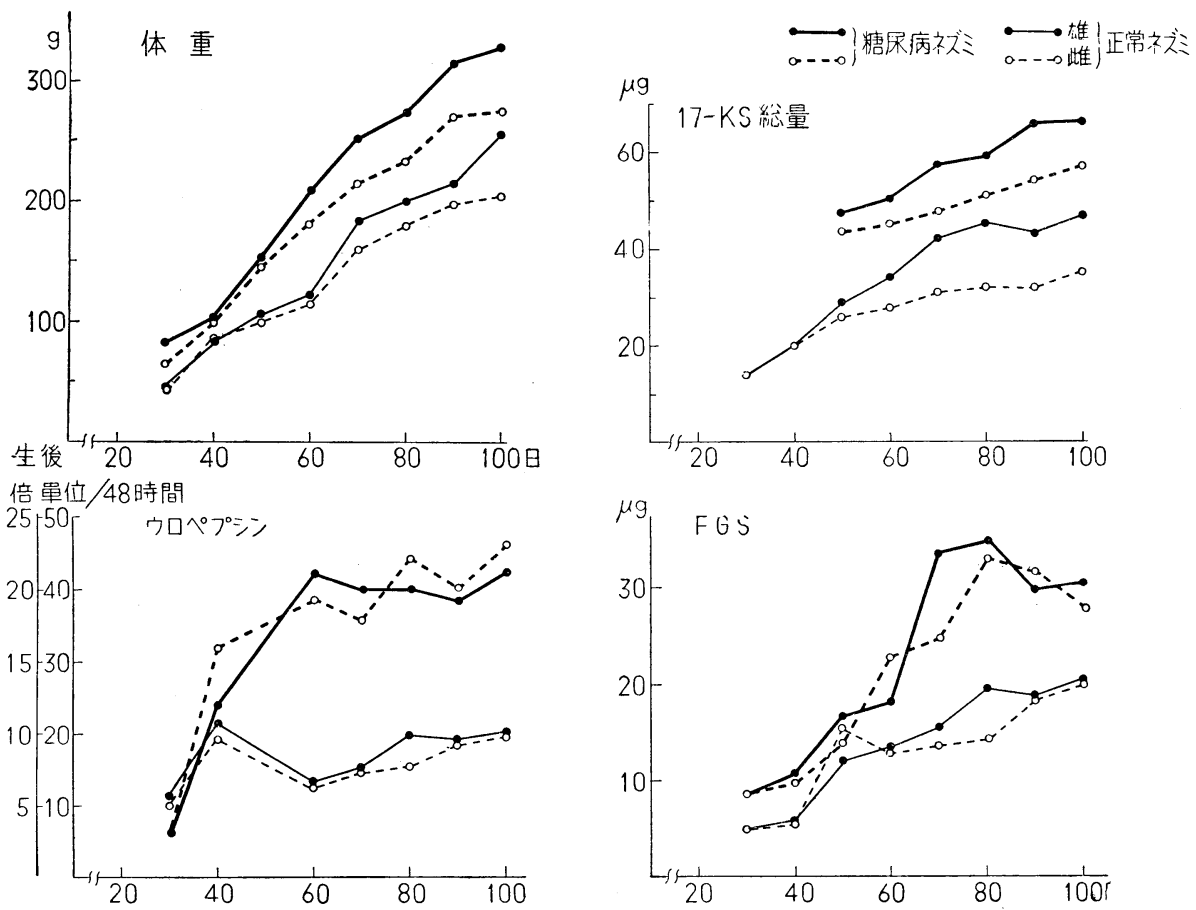

17-OHCS，ウロペプシンが増加しているとと1)5455)功れらのウサギがアロキサン糖㽷病ウサギとととな り副腎皮質機能九進のあるものと推定されている。そして私は種種の程度に先天性糖尿病素因をむつ歴代両 親実験的糖尿病子孫ウサギおよび Wistar 系シロネズミにアロキサン糖尿病を発症させ，その尿中17-KS総 量ならびに分劃を測定し，ネズミではさらに FGS，ウロペプシンの測定をも行つて正常およびアロキサン 糖尿病発症動物ならびに実験的先天性糖尿病動物の結果と比较して一定の成績を得た. 次にこれら成績につ いて若干の考按を加えたいと考える. 


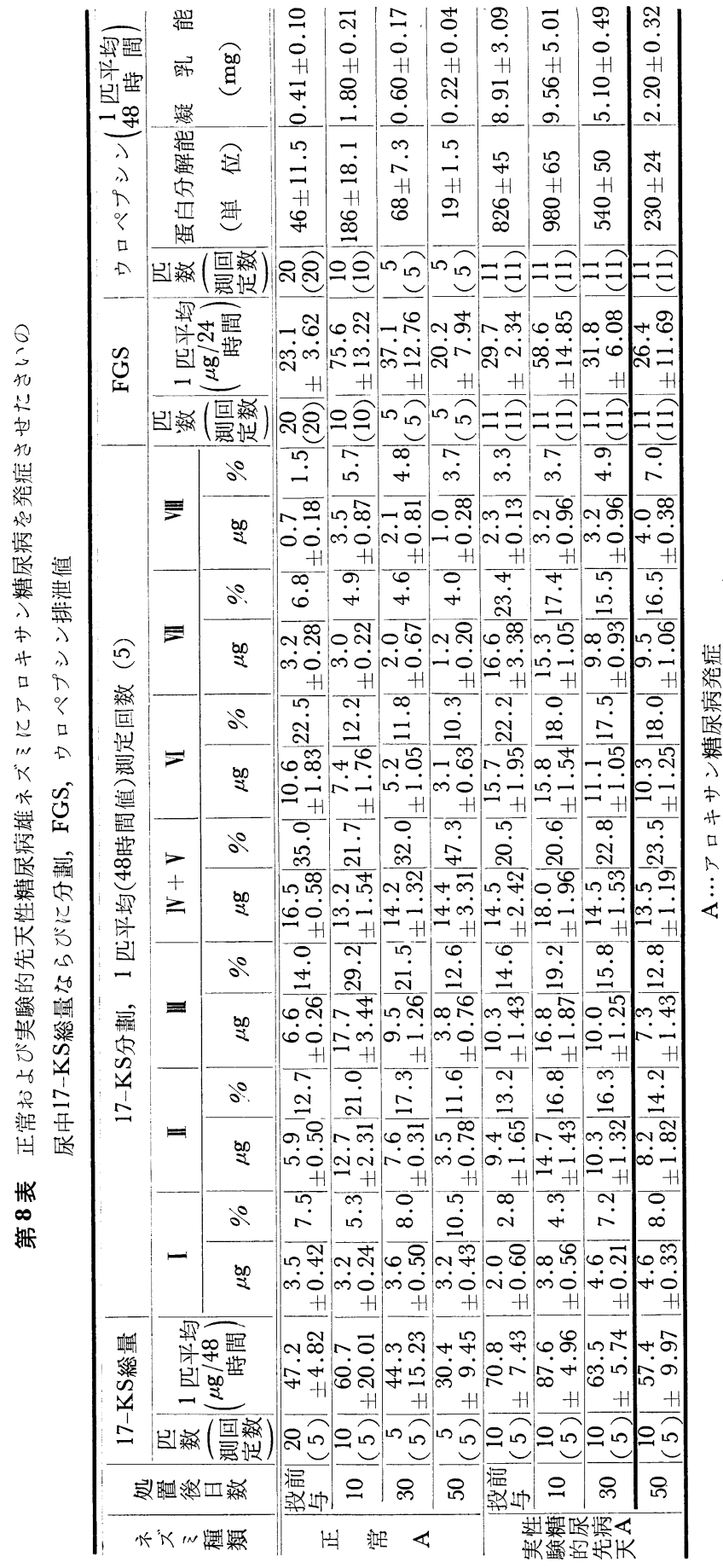

( I ) ウサギの研究成績について 正常成熟ウサギの尿中 $17-\mathrm{KS}$ 総量 について私の得た測定值は同じ方法 で測定した鈴木 ${ }^{67)}$ ，赤沢 ${ }^{1)}$ の得た値 とほぼ同じであつた，ウサギ尿中 17-KS值む人間での報告 ${ }^{15) 16)}$ 之同様 に雄が雌より高值を示した。 これは 尿中17-KSが雄では等丸上副䇾皮質 に由来し，雙では副腎皮質にのみ由 来するためと考えられる。 そして 17-KS 分劃については私あ赤沢1 同様に 8 分劃のクロマトグラムを得， その各分劃の得た位置は赤沢む述心 ているように Edwards ${ }^{18)}$, 大野 ${ }^{57) ら ~}$ が各17-KSの純結晶および人体尿中 17-KS分剖で得た位置と一致してい るので，ウサギの尿中ケトステロイ ド代謝が体と類似しているという 赤沢 ${ }^{1)}$ の考えは妥当なあのであ万う.

a）歴代実験的糖尿病子孫ウサギ 世代の浅い糖沓病子孫ラサギでは 膵ラ氏島の発育障碍は軽度で先天性 糖尿病素因の程度は弱く糖尿病を自 然発症するに至らないが，之の尿中 17-KSは軽度の増加を示し, 代を累 ねるにつれて増加の度が搔くなる。 そしてその17-KS分劃像も, 代を累 ねるにつれII, III分劃, ついでII, VIII分劃がぜんじ増加の傾向を示して くる，さらに世代がすすんで糖尿病 を自然発症するに至つたウサギ，す なわち実験的先天性糖尿病ウサギで は尿中17-KS総量, その II, III, V, 川分劃の増加は最む顕著である。乙 れらの成績は赤沢 ${ }^{1)}$ の報告とよく一 致している.さらに赤沢1) はてのよ うなウサギにおいてウロペプシンの 増加を屯認め, 笆野ら ${ }^{66}$ は副珡皮質 の束状首を主体とする皮質各屏に好 酸性粗大顆粒をむつ充実性肥大細胞 をみ, さらに深首網状首, 傍䯣層に

およぶとともに著明な皮質面績の增大を伴う之報告している。これらの所見とあわせ考え，乙のようなウサ ギの尿中17-KS総量, 分劃の増加像はその副㸼皮質の機能儿進を示すむのと考元られる. 
第 7 図正常雄ネズミ招よび実験的先天性糖疗病雄ネズミにアロキサン糖尿病を 発䇛させたさいの尿中17-KS分劃
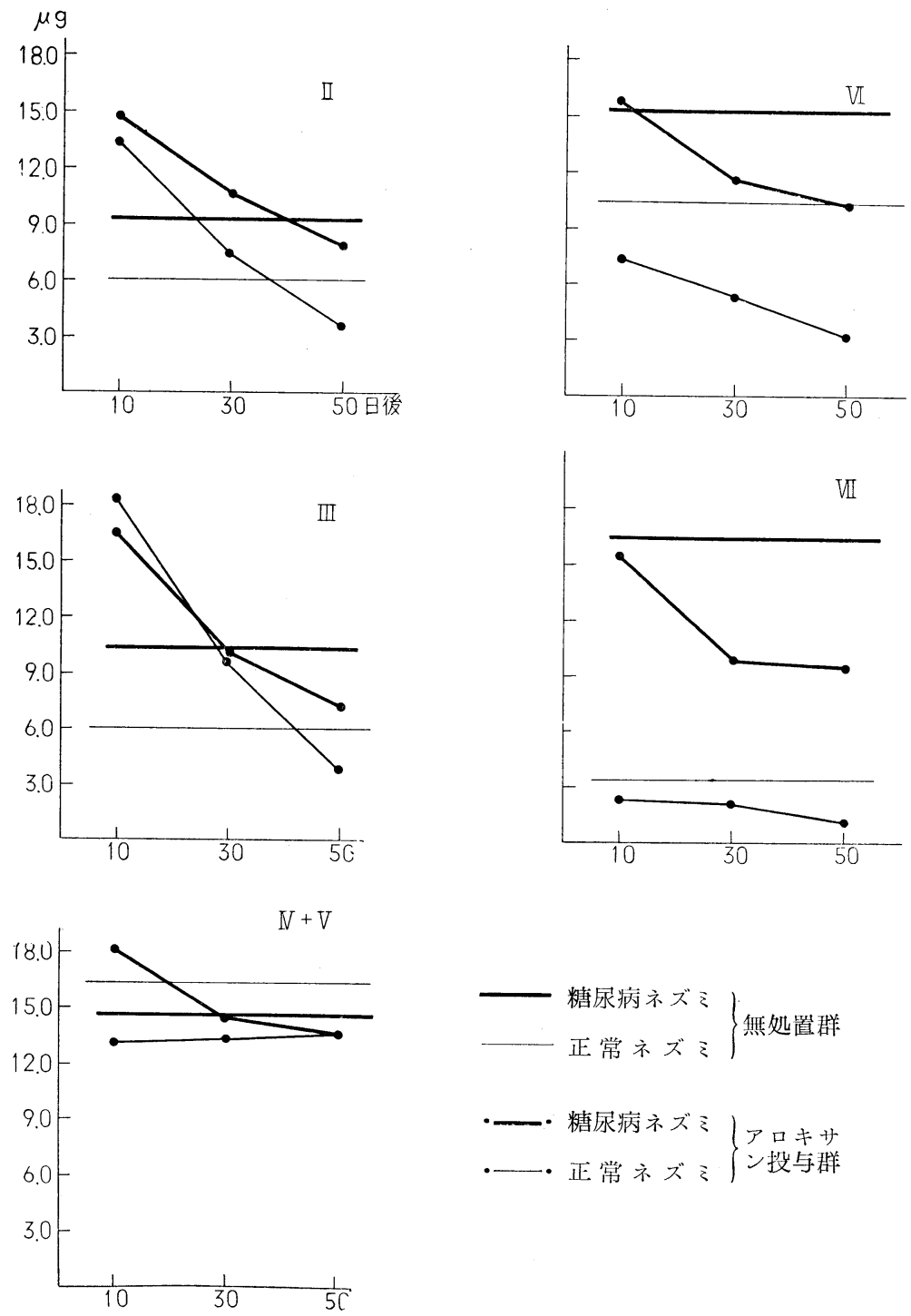

一一・糖尿病ネズミ|アロキサ ・——正常ネズミ\}ン投与群

b） 歴代実験的糖㽷病子孫ウサギにアロキサン糖尿病を発症させた場合

先天性糖尿病素因を種々の程度に有するウサギにアロキサン糖尿病を発症させたさいのケトステロイド代 謝を追究するために, 歴代両親実験的糖尿病子孫ウサギや糖尿病を自然発症する程先天性糖尿病素因を濃厚 に有するウサギの糖尿病非発症時期にアロキサン糖尿病を発症させたウサギについて㽷中17-KS 総量ならび に分劃をしらべ，その測定結果を上述のこれらのウサギの無処置の結果および正常ウサギにアロキサン糖尿 病を発症させたさいの結果と比較してみた。

まず正常成熟ウサギにアロキサン糖䐂病荤症させたさいのケトステロイド排泄状態はすでに赤沢1が 17-KS総量は発症 7 日〜 14日後の間に最高值を示し，30日後にほぼ発症前值となり200日後，300日後には減 
少を示し，その分劃も各分劃が正常值以下に減少し，とくにVI，VII分劃の減少が著明であると報告している. 私もアロキサン糖尿病発症50日以後のものについて測定を行い同様の結果をえた. 次に歴代実験的糖尿病子 孫ウサギにアロキサン糖尿病を発症させたさいのケトステロイド排浛状態はアロキサン投与の影響をうけ,

17-KS総量は無処置群にくらへて各世代とも減少しており，その值は世代の浅いあのは正常值以下に，世代 の与すんだ糖尿病の自然発症をみる世代のものは, 正常值より高い值を示している. 分劃像も II, III, II, 卭分劃が無処置群にくらへ減少を示すが，正常值よりも高值である．正常ウサギのアロキサン糖尿病の埸合 とくらべると，17-KS総量ならびに全分劃が高く，その差は先天性糖尿病素因を濃厚に有する世代のすすん だウサギほど大きく，すなわちアロキサン糖尿病発症による影響が少くなつている，上記のように実験的糖 疗病子孫ウサギでみられたケトステロイド排泄増加は副腎皮質機能充進によると考えられるが，これらのウ サギにアロキサン投与という外的な糖尿病発症要素が加わつて糖尿病を発症した埸合, 副腎皮質機能が障碍 され，ケトステロイド排泄状態はアロキサン糖尿病発症前の特長を残してさまざまな值を示すあのと理解さ れる。

\section{（II）Wistar 系シロネズミの研究成績について}

ネズミの尿中17-KS測定については安藤ら ${ }^{233)}$ は一般に粘液様物質が多く Zimmermann 反応を与皃る Chromogen，いわゆる非ヶトン分劃が多く，17-KSの排泄量は少く，非ケトン分劃の中性分劃に対する百分率が 40〜75\%の高率を示すと報告し，そして Girard 分析が必要であると述べている，私はネズミの尿中17-KS 総量の測定にさいし，48時間尿を用い30\%の塩酸を加えて $80^{\circ} \mathrm{C} て ゙ 30$ 分間加水分解を行つた. Girard 分析を 行つて非ケトン分劃を除き, 分離したケトン分劃は $8 \mathrm{~N}$ 苛性カリと $1 \%$ meta-Dinitrobenzeneで Zimmermann 反応を行つた．このさいネズミの飼育条件を一定にし環境の変化によると考えられる条件を少くするよ うにつとめた。正常成熟ネズミの 48時間沓における雄 20 匹平均值は $46.8 \pm 3.82 \mathrm{~g}$, 雌 20 匹平均值 $34.5 \pm$

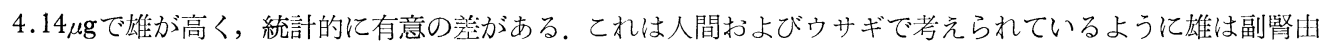
来のステロイドの他，性腺由来のステロイドが関与するためと考えられる．従来の報告では Girard 分析を 行わずに，Del Greco ら ${ }^{13}$ は雙ネズミで198 $\pm 7.2 \mu \mathrm{g} / 24$ 時間, Bucchus ${ }^{5)} は 137 \pm 7 \mu \mathrm{g} / 24$ 時間之報告している. また Girard 分析を行つて Danford ら ${ }^{11)}$ は雄ネズミで $30, \mathrm{~g} / 24$ 時間と報告しているが，発色にさいし $2.5 \mathrm{~N}$ 苛性カリと $2 \%$ meta-Dinitrobenzene を用いている。安藤 ${ }^{23)}$ は塩酸 $20 \%, 80^{\circ} \mathrm{C} ， 30$ 分間の加水分解が最 適とし, Girard 分析を行い，発色は $5 \mathrm{~N}$ 苛性カリ， $25^{\circ} \mathrm{C}, 110$ 分が安全であると述べている，そして雄 32.5 ～39.7 $\mu \mathrm{g} / 24$ 時間，雌32.6 20 $\mu \mathrm{g} / 24$ 時間と報告しやはり雄か踓より高い. これは私の測定結果よりやや高い 值である。

ネズミ尿中17-KS分劃についてはクロマトグラムにおいて雄, 雌とあほぼ8 分劃に分れ, 各分劃のクロマ トグラム上の位置は人間における Pond ${ }^{(1)}$ ，Edwards ${ }^{19)}$ ，大野福らの報告や，ウサギにおける赤沢 ${ }^{1)}$ の報告之 大体同一場所に Zimmermann 反尤物質の排泄があつた，各17-KSの純粋結晶の同定からその II， II 分劃は $\beta$ 17-KS と考え弓れる．VI，田分劃についてみると，人間の場合八イドロコーチゾンの代謝産物とされている が๋ ら主にコルチコステロンと 11-oxy-17-KS を証明し, McCarthy"37) 17-Hydroxycorticosterone とコルチコ ステロンを血中より測定しているのでやはりネズミのVI，UI分劃は副腎由来のあのであろうと考える， $\mathrm{N}+$ V分劃についてみるに人間ではIV分劃は Androsterone，V分劃は Etiocholanolone と考兄れており ${ }^{15)}$, ウサギおよびネズミでは両者の分離は不鮮明なので両者を $\mathrm{N}+\mathrm{V}$ 分劃としているが，正常ネズミの雄が雌よ りこの分劃が高いのはウサギ，人間の場合のように性腺由来のステロイドが排泄されてくるためであろう.

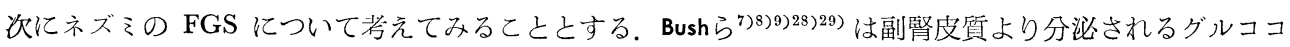
ルチコイドは動物により差異があり, ネズミではコルチコステロンが多く, 八イドロコーチゾンは少いか, またはない之報告した。 ハイドロコーチゾンは特異の呈色反応を示す Porter-Silber 反応 ${ }^{63}$ で測定できるが C-17位にOH基をもたないコルチコステロンの測定には適当でなく，また安藤"3かが指摘しているようにネズ ミ尿中17-KS測定にさいし非ケトン分劃が多く，副整皮質機能を知るにてれだけでは充分とはいえないと考 
える、Talbot ら ${ }^{70)}$ は Zimmermann 父応で測定できない Girard 分析で得た非ヶトン分劃から過沃度酸酸化 により17-KSになるステロロイドみつけた．また過沃度酸酸化でG-17位の側鎖が分解しフオルムアルデヒド 在生ずる.とのととからその形成されれてオルムアルデヒドの定量在行い Cor(oran ${ }^{10)}$, Loewenstein ${ }^{34)}$, Daughaday $^{12)}$ らが人間のコルチコイドの測定に応用した. Daughaday ${ }^{12)}$ が行つたこのような FGS の測定法在 Burstein $^{6}$ が㗢物に応用し，モルモットに AGTH を投与しその尿中コルチコイドの消長を測定し，Halama ${ }^{27)}$ は寒玲ストレスによりモルモットの尿中 FGS の值から副肾皮質機能を研究している。村中 ${ }^{4243}$ はネズミに

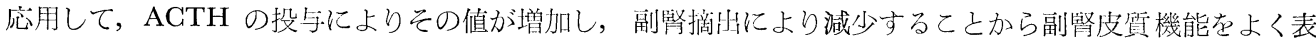
示するとのべ，雄ネズミで $25.23 \pm 5.44 \mu \mathrm{g} / 24$ 時間之報告している。私は村中の方法在参考にして正常成熟市

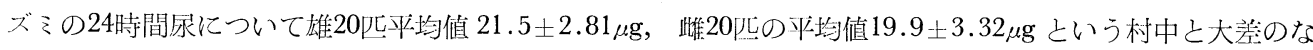
い值を得た．雄，雔間に統計的に有意の差はなかつた。従来の報告ではKalant ${ }^{31)}$ は雄ネズミで Daughaday

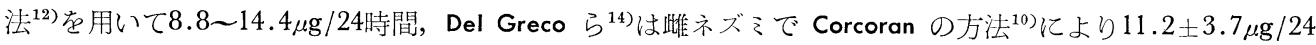
時間と私よりやや低い值を報告している.

ネズミの成長时の測定結果は生後80日位まで増加をみ，その後は大体一定した值を得ている。植手 ${ }^{74)}$ 成

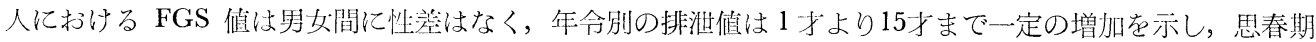
以後は略一定の值を保つと述心゙，私のネズミの成績とよく似ている。三宅 $\left.{ }^{40}\right)$ はGS 值之17-KS值との間に 必ずしも密接な並行是係はないと述心゙ているが，私の成績でも第 6 図にみるようにきれいな並行関係はみら れない。

尿中ウロペプシンの测定については $\mathrm{Gray}^{25)}$ ，竹腰 ${ }^{72)}$ ，田多井 ${ }^{73}$ らの報皆があり，竹腰はネズミの下垂体， 副腎を摘留すると尿中ウ口ペプシンが低下し，コーチゾンを与えると増量すると述心てているからネズミのウ ロペプシンも間接的な副腎皮蜇機能の指標になると考えられる.

a）実験的先天性糖尿病ネズミ

尿中17-KS総量は糖尿病未発症㭃若時より导でに正常ネズミにくらべて増量を示し，発症時に高く2 倍值

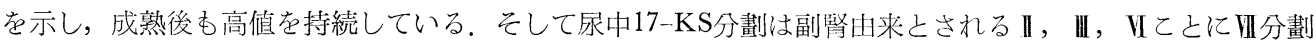
が対照正常ネズミにくらべ増加が著しい，乙れは糖㽷病未発症㭃若時よりみられ，成熟後は顕著である。さ らに尿中 FGS は生後30日の㭃若時よりすでに対照正常ネズミより增加しており，糖疗病の自然発症をみる 70 日頃は正常值の 2 倍となり，以後もなお高值を持続する．尿中ウロペプシンも前述の 17-KS 值，FGS 值 の增加, 副腎由来とされる分劃の増加等に立行して正常值にくらべ著しい増加がみられた。

以上の結果加ら実験的先天性糖尿病ネズミの副腎皮犋機能は杂進していると推定される。そしてての所見

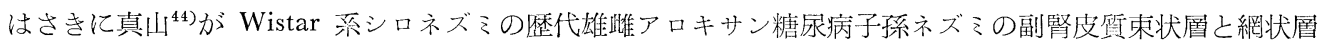
面積の増加を述べ，斉藤 ${ }^{65}$ はこれらの幼若ネズミの副婜皮質面積の増加を述べているととと一致するものと 考えられる.

b）実験的先天性糖㽷病ネズミにアロキサン糖尿病を発症させた場合

尿中17-KS総量はアロキサン投与後に一過性に增量する。すなわち実験的先天性糖尿病ネズミでも正常ネ ズミでも，投与10日後に増加がみられ，30日後，50日後と減少している。しかし実験的先天性糖尿病ネズミ のアロキサン投与による17-KS值の変㗢は，正常ネズミにアロキサン糖尿病を発症させたさいとととなり投 与50日後も，その值は正常值より高く，後者は正常值以下に低下する.

㽷中17-KS分劃はアロキサン投与10日後に II， III， IV + V 分劃の増扸がみられ，以後ぜんじ各分劃の值は 減少してゆくが，正常ネズミにアロキサン糖尿病を発症させたさいとととなり，副腎由来と考えられるI，

III， II， III分劃は対照正常值よりなお高い.

以上の結果は前述のウサギで得た成績とよく一致している。

㽷中 FGS は実験的先天性糖尿病ネズミのアロキサン糖㽷病発症のさいは，アロキサン投与.10日後に投与

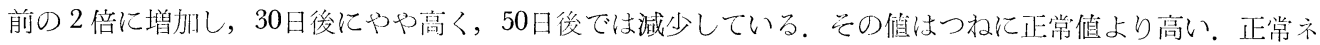
ズミにアロキサン糖疗病を発症させたさいは，投与10日後に投与前值の 3 倍となり，30日後の值は1.6倍に 
娍少し，50日後には投与前值を示している。ささらに長期間糖氺病を持続したものでは正常值以下に娍少して いる. Kalant ${ }^{31)}$ 㳉雄ネズミにアロキサン $200 \mathrm{mg} / \mathrm{kg}$ を腹腔内に投与して糖尿病在発症させ 3 週間から 4 週間

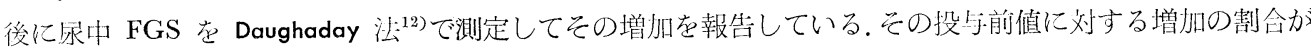

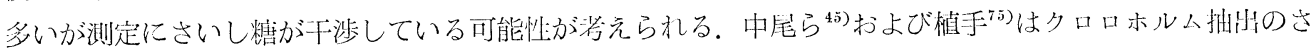
いアルカり淮で洗滌することによりブドり糖等の非特異的な下渉物質が除きうると報告して扔り，私はこれ 苍行つて上述の絬果を得たのである。

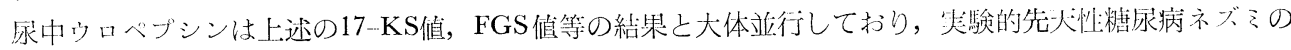

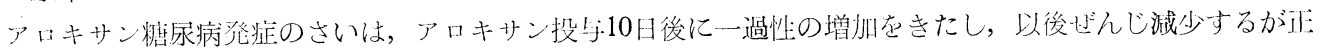
常ネズミのアロキシン糖永病のさいとことなり50日以後の場合も正常值以下にはならない。

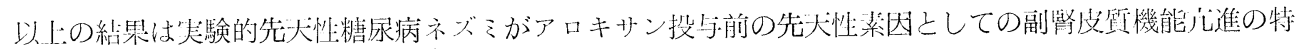
長危残し，アロキ+ンによる影響が少いとと赤している。

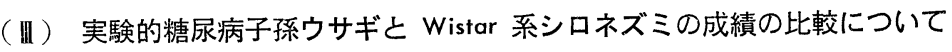

前述の上うに私は歴代奏験的糖尿病子孫りサギならびに実験的先天性糖尿病子孫りサギの尿中17-KS值は 正常ウサギにくらべて妙若時より增加し，上くに成熟後は高值を示し，またその17-KS分劃像において，I， III， II，四分劃か增加する成績を得た。一方笑験的先天性糖䐂病ネズミの17-KS総量ならびに分劃について

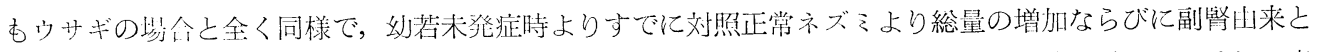

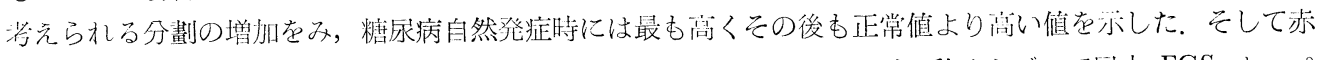
泥1はこのようなりサギで17-OHCS，ウロペプシンの增加を述べているが，私はネズミで㽷中 FGS，ウロペ プシンの測定を行い，いずれむ正常ネズミの值より著明な增加を認めた。こして上述の笹野ら ${ }^{66}$ のとれらら サギの副腎皮質組織像に関する研究や真山 ${ }^{4 t)}$, 斉藤(5)らの糖尿病子孫ネズミの副腎皮質に関する研究はやは り副婜皮質の機能充進を裏付けている.

次にこれらの動物にアロキサンを投与したさいの影響についてみるに，赤沢1 は正常ウサギにアロキサン 糖䐂病を発症させたい17-KS総量, 分劃，17-OHCS，ウロペプシンは一時的の増加の後正常値以下に減少す ると報告し, 私も17-KS総量, 分劃について同様の成績を得た。こしててれは今回私の行つたアロキサン糖 尿病ネズミの17-KS総量, 分劃, FGS, ウロペプシンの成績ともよく一致している.

奏験的煻尿病子孫ウサギのアロキサン糖尿病のさい50日以上，長期間糖尿病を持続したさいは各世代いず

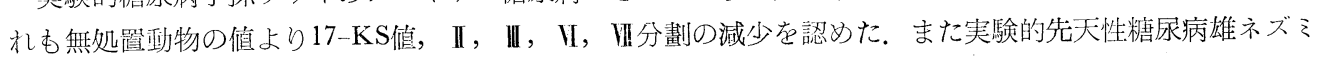
のアロキサン糖辰病発症のさいす全く同椂に投与10日後に一特的な17-KS值, FGS值, ウロペプシンの增加 と II， II 分劃の增加をきたすが，以後ぜんじ低下像を示した。したがつて生来副腎皮質機能九進を有するて 机らの動物にアロキサン糖沓病を発症させたさいは発症前値にくらべ17-KS 值, FGS 值, ウロペプシン等

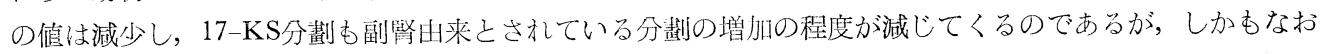
発症前の特長あるケトステロイド代謝の像学種々の程度に保つことを認妨次第である。

（IV）実験的糖尿病ウサギならびにW Wistar 系シロネズミの研究成績と人体糖尿病のさいの副腎皮質機能

私の研究成績は，(a) 正常りサギならびにネズミにアロキサンを投与したさいは，投与後一時的に 17-KS 総量, II, III 分劃, ネズミの㽷中 FGS, ウロペプシンの増加の後, 減少してりき糖尿病を長期間持続する屯

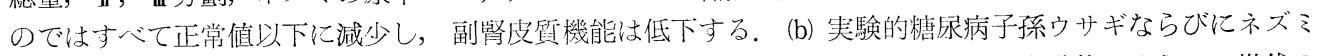
では，17-KS 総量，II， III， II， III分劃，ネズミの尿中 FGS，ウロペプシンが，正常動物にくらべて世代の

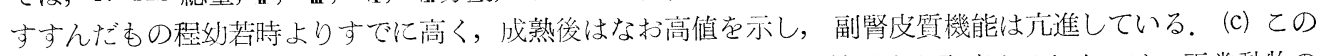

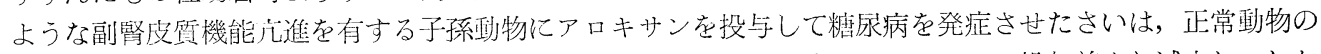
アロキサン糖存病の場介之同様に一侍的に各測定值は增加するが後にはアロキサン投与前より減少し，しか

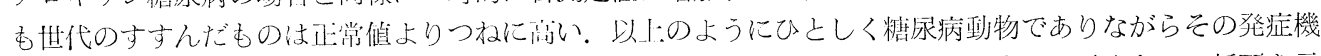

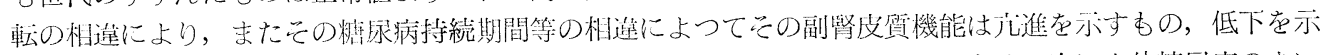
すあの，己の中間でいろいろの像を示すむの等いろいろであることをみたのである．次に人体糖尿病のさい のステロイド代謝に関する報告をみるに, White $\mathrm{e}^{\text {77) }}$ 洗天性糖疗病之推定される小兄糖尿病では発症期前後 


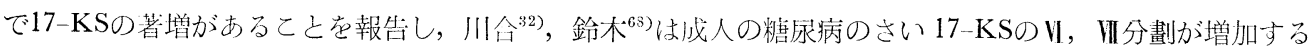

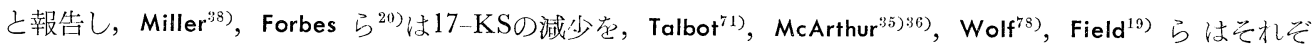
れコルチコイドや FGS 值の減少を, さらに大野 ${ }^{57}$ は29例の17-KS值をしらべ正常値18例, 低做 7 例, やゃ

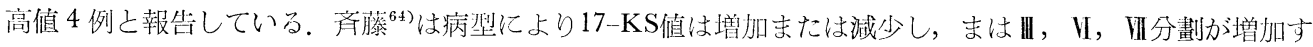
るあのがあると報告している状態であつて, 要するにその成績はいらいらである。人体糖症病のさいのステ ロイド代謝状態を考えるさい，当然二次的病変の合併等を考慮に入れるべきものであらうが，さらに私の動 物実験の成績から按じてその発症にどれだけ先天性糖㽷病素因が䦥与しているかによつても大きく左右され るものであろうと考えるのである.

\section{第 5 章＼cjkstart総括ならびに結論}

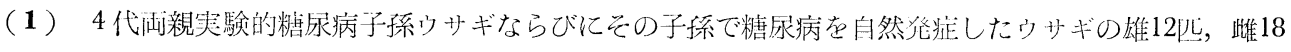
匹とこれらの糖疗病非発症ウサギにアロキサン糖㽷病を発症させた雄13匹，雌10匹の㽷中17-KSならびに分 劃を測定し，正常ウサギ雄 9 匹，雌 6 厄ならびにアロキサン糖㽷病ウサギ雄 7 匹，雌 8 拒の测定值と比較し 次の絬杲を待た。

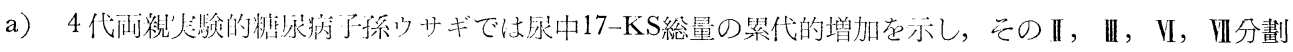

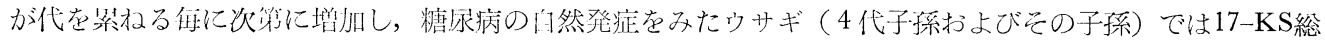
量は正常値の1.5〜 2 倍に増加し，そのII， III， II, VII分劃の著明な増加在示す。

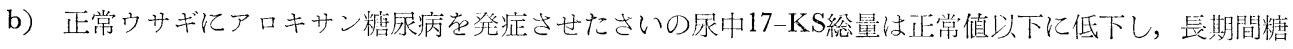
尿病を持続するものではことに著しい.

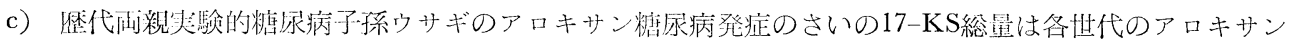

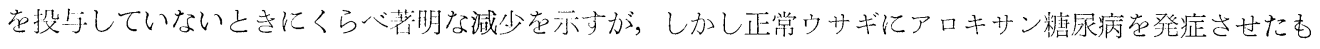
のより壃加し，しかあ世代がすすす程増加している。その值は正常佔に比較してはじめの世代では著しく減 少しているが，後の世代では正常㑤より整度の増加を示す。17-KS分劃は各世代とむアロキサンを投与しな いものにくらべ，全分劃の減少がみられるが，正常ウサギにアロキサン糖尿病を発症させたさいよりはじめ の世代では III, $\mathrm{IV}+\mathrm{V}$ 分劃以外の分劃は高く, 世代がすすむ程その II, III, $\mathrm{I}, \mathrm{II}$ 分劃の增加の傾向がみら れる。

d）実験的先犬性糖永病子孫りサギの糖㽷病非桨症時にアロキサン糖尿病を発症させたさいの17-KS総量

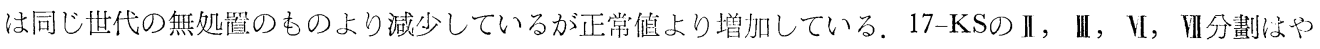
はり無処犆のものより減少しているが，なお正常值より增加している。

（2）実験的先天性糖尿病 Wistar 系シロネズミ雄20匹，雌24匹と，乙の雄ネズミ11匹にアロキサン糖尿 病を発症させたさいの尿中17-KS総量, 分劃, FGS，ウロペプシンの測定值を正常ネズミ雄，雌各20匹とア ロキサン糖尿病ネズミ雄16匹，雌 5 匹の結果と比較し次の結果を得た.

a）実験的先天性糖尿病ネズミは刘照正常ネズミより17-KS総量, FGS值, ウロペプシンは高く, 17-KS

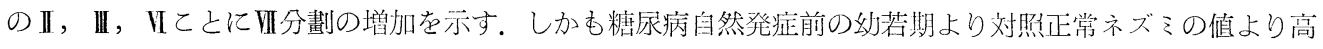
く，生後70日から80日頃に最高值を示しその後もこの伹を維持する.

b）正常ネズミにアロキサン糖㽷病在㚪症させたさいはアロキサン投与後10日頃に17-KS総量，FGS值， ウロペプシンは一過性に増加し，II， III 分劃も增如するが，投与50日以後では各測定值は投与前値より減少 学示す.

c）実験的先天性糖尿病雄ネズミにアロキサン糖㽷病在発症させたさいはアロキサン投与後10日頃に正常

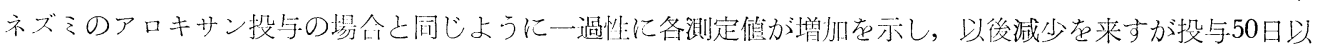
後では投与前值よりすべて低下する。しかしいずれも正常值より高倠虎たもつ，なお17-KS分劃は投与後10 日頃に全分劃の增加をみ，以後減少を来すが II， II，田分劃は正常値より高值を示す。

(3) 以上の結果加ら次のようと結論する. 
a）笑験的糖尿病子孫ウサギ，Wistar 系シロネズミの副票皮質機能は累代的に光進する.

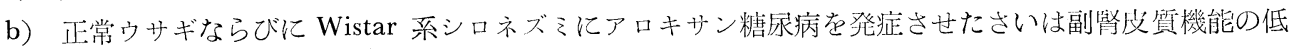
下を示吉。

c）夷験的糖永病子孫ウサギならびに Wistar 系シロネズミにアロキサン糖㽷病を発症させたさいは，副

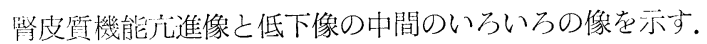

附記 本研究に対し種々の御教示をたまわつた赤沢好温博士，FGS測定法黨御教示下ささて村中日出夫博 士に樑苌の謝意を表します。.

\section{文献}

1）赤沢好温：止常ならびに垁験的先天性糖尿病ウサギの尿中17-KS総量ならびに分蝟，17-OHCS，ウ口バ プシンについて，日内分泌誌，35，776〜849，昭 34

2）安藤晴弘，広頼欣一：ラットの尿中17-KS の測定について，日内分泌誌，33，900～904，昭33

3) 安藤晴弘：小動物に打ける17-Ketosteroids, 内分泌之代謝，2，233～236，炤34.

4) Anson, M.L. \& Mirsky, A.E. : The estimation of pepsin with hemoglobin, J. Gener. Physiol., 16, 59 63, $1933 . \quad 5)$ Bucchus, H. \& Heiffer, M.H. : Urinary corticosteroids and 17-ketosteroids in adrenalectomized female rats treated with cortisone and ascorbic acid, Am. J. Physiol., 173, 33 36, 1955.

6) Burstein, S.: The guinea pig as a laboratory animal for corticoid excretion studies: Modification of the formaldehydogenic method, Endocrinology, 50, 412 418, 1952.

7) Bush, I.E. : Paper-chromatographic study of the secretion of the adrenal cortex in various mammalian species, J. Physiol., 115, 12 13, 1951.

8) Bush, I.E. : Species differences in adrenocortical secretion, J. Endocr., 9, 95 100, 1953.

9) Bush, I.E. : Recent work on the secretion of the adrenal cortex, Schw. Med. Wsch., 85, 645 648, $1955 . \quad 10)$ Corcoran, A.C. \& Page, I.H. : Methods for the chemical determination of corticosteroids in urine and plasma, J. Lab. \& Glin. Med., 33, 1326 1333, $1948 . \quad 11)$ Danford, P.A. \& Danford, H.G. : Influence of sodium chloride deficiency upon urine volume and 17-ketosteroid excretion in the rat, Am. J. Physiol., 14, 690 694, 1951. 12) Daughaday, W.H., Jaff, H. \& Roffert, H.W. : Chemical assay for "cortin", determination of formaldehyde liberated on oxidation with periodic acid, J. Clin. Endocr., 8, 166 174, 1948. Del Greco, F., Masson, G.M.C. \& Corcoran, A.C. : Effects of $\mathrm{C}_{17}$-hydroxy-steroids on urinary 17-ketosteroids in the rat, Proc. Soc. Exp. Biol. \& Med., 80, 354 357, 1952.

14) Del Greco, F., Masson, G.M.C. \& Corcoran, A.C. : Effects of corticosteroids on urinary formaldehydogenic corticoids and 17-ketosteroids in normal and subtotally hepatectomized rats, Endocrinology, 52, 474 483, 1953.115$)$ Dingemanse, E., Huis in't Velt, L.G. \& Hartogh-Katz, S.L. : Clinical method for the chromatographic-colorimetric determination of urinary 17-ketosteroids. II. Normal adults, J. Clin. Endocr. \& Met., 12, 66 85, 1952. 16) Dingemanse, E., Huis in't Velt, L.G. \& de Laat, B.M.: Chemical method for the chromatographic colorimetric determination of urinary 17-ketosteroids, Clin. Endocr., 6, 535 548, 1946. Drekter, I.J.,Pearson, S., Bartezak, E. \& Mcgavak, T.H. : A rapid method for determination of total urinary 17-ketosteroids, J. Clin. Endocr., 7, 795 800, 1947.

18) Edwards, R.W.H. : The determination of adrenocortical steroids and their metabolites, 53, Dennis Dobson, London, 1954.

19) Field, J.B. \& Marble, A. : Diminished adrenal cortical function in diabetes as shown in eosinophil response to stress of surgery, Proc. Soc. Exp. Biol. \& Med., 77, 195 198, 1951.

20) Forbes, A.P., Donaldson, E.C., Reifenstein, E.C. \& Albright, F.Jr. : The effect of trauma and disease on the urinary 17-ketosteroid excretion in man, J. Clin. Endocr., 7, 264 288, 1947.

21）福住一三，赤沢好温，川合一良：ウ

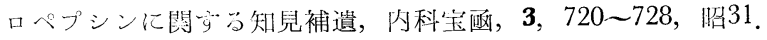

22）福留金一郎：4 代打よび 5 代 アロキサン糖尿病兩漞から生れたウサギに抢、当自然発症性糖尿病の経過と諸内泌藏器の病理組織学的所見, 
東北医誌，55，468～485，昭32.

23）藤井暢三：生化学実験法。定性編，3 版，56，南山堂，東京， 昭17. 24) Gray, S.J., Ramsey, C., Reifenstein, R.W. \& Benson, J.A. : The significance of hormonal factors in the pathogenesis of peptic ulcer, Gastroenter., 29, 156 172, 1953.

25) Gray, S.J. \& Ramsey, C. : Adrenal influence upon stomach and gastric responses to stress, Recent Prog. Horm. Res., XIII, 583 617, Academic Press, New York, 1957.

26) Hadd, H.E. \& Perloff, W.H. : A simplified distilling head for the measurement of corticosteroids by the formaldehydogenic method, J. Clin. Endocr. \& Met., 16, 138 140, 1956.

27) Halama, A.K. : The determination of formaldehydogenic corticoids in guinea pig urine, Endocrinology, 57, 641 645, 1955.

28) Hoffmann, F.G. : The in vitro hydroxylation of 21-carbon steroids by rat adrenal glands, Endocrinology, 60, 382 389, 1956. 29) Holzbauer, M. : The corticosterone content of rat adrenal under different experimental conditions, J. Physiol., 139, 294〜305, 1957. 30) 井関満夫 : 実験的先天性糖尿病ウサギ $\left(\mathrm{F}_{1}\right.$ 〜 $\left.\mathrm{F}_{4}\right)$ の経過ならびに 諸内分泌㵴器の病理学的研究, 日内分泌誌, 36, 1169 1211, 昭35. 31) Kalant, N. : Adrenal function in alloxan diabetes, Am. J. Physiol., 82, 503 506, 1955.

32) 川合一良 : 尿17ーケトステロイド分劃 亿関守万臨床的研究, 北野紀要, 4, 254 281, 炤34.

33) 河田竜夫：統計学概論. 改訂版, 101, 文耀社，東京，昭26。 34) Lowenstein, B.E., Corcoran, A.C. \& Page, I.H. : Determination of corticosteroid in urine, Endocrinology, 39, 82, $1946 . \quad 35)$ McArthur, J.W., Sprague, R.G. \& Masson, H.L. : The urinary excretion of corticosteroids in diabetic acidosis, J. Clin. Endocr., 10, 307 312, 1950. 36) McArthur, J.W., Chao, D.H.C., MacLachlan, E.A., Morrill, M.F., Campbell, A.M., Wood, M.D., Zygmuntowicz, A., Goets, F.C. \& Sveinsson, S.L. : A metabolic study of a diabetic patient. The cffect of variation in the dosage of insulin upon adrenal cortical activity and upon water electrolyte and nitrogen excretion, J. Clinic. Invest., 31, 592 597, $1952 . \quad 37)$ McCarthy, J.L., Corley, R.C. \& Zarrow, M.X. : Effect of goitrogens on adrenal gland of the rat, Am. J. Physiol., 197, 693 698, $1959 . \quad 38$ ) Miller, S. \& Mason, H.L. : The excretion of 17-KS by diabetes, J. Clinic. Endocr., 5. 220 225, $1945 . \quad 39)$ 三宅 儀, 扇谷正彦 : ちんめるまん反応の応用, 日内分泌誌, 26, 122 132, 炤25. 40) 三宅 儀 : For-

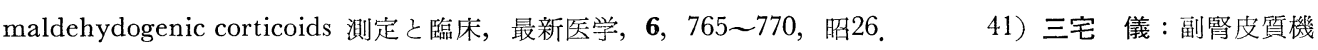
能検查比判，最新医学，15，1280～1287，昭32. $42 ）$ 村中日出夫，説田 武：白鼠打よび 2,3 実験 動物の尿中 Corticoids, 特飞 Formaldehydogenic corticoids について, 日内分泌誌, 34, 303〜304, 昭33. 43) Muranaka, H.: Studies on the urinary formaldehydogenic steroids in albino rats under various experimental conditions, Acta Scholae Med. Univ. in Kioto, in press.

44) 真山 進 : 歴代雌雄了 ロキサン糖尿病扣よび歴代雌雄アロキサン糖尿病発症防止シロネズミ（Wistar系）より生れたシロネズミの 諸藏器細胞ならびに組織の計測的研究, 東北医誌, 57, 1 23, 昭33. 45) 中尾 健, 稲葉 稔: Marrian の所謂尿中 “Formaldehyd retaining substance” 飞関守る研究，日内分泌誌，32，128１29，昭31. 46) 那 須聰：実験的糖尿病ウサギならびにその子孫ウサギの副腎捛よび下垂体の計測的組織学的研究, 神戸紀 要, 8, 67 91, 昭31. 47) 岡本耕造 : 糖尿病の実験的研究, 日病理学会誌, 41(総会号), 27〜43, 昭27, 48) 岡本耕造, 関 東源, 福留金一郎, 藤木竜也, 小松欣一郎 : 正常门サギ, 糖尿病ウサギのラ氏島ならびに 累代糖尿病ウサギの子孫のラ氏島の訃測的研究，日病理学会誌，42，(総会昂），54～56, 昭28.

岡本耕造, 福留金一郎：4 代または 5 代糖尿病党発症さした雙雄りサギより生れたウサギ $\left(\mathrm{F}_{4}, \mathrm{~F}_{5}\right.$ ウギ） に打ける糖尿病の自然発症について，日病理学会誌，43，(総会号），187～192，炤29. 50）岡本耕造， 福留金一郎, 的場直矢, 入江一彦, 菅原 仁, 小関 要, 真山 進, 中嶋 賢, 南部四郎, 高橋泰克 : 歴代糖尿 病動物の子孫動物に扎けるラ氏島の発育障碍, 糖尿病の自然発症及びその発生機転に関省る研究, 日病理学 会誌，44，(総会号)，200２01，炤30. 51) Okamoto，K. : Experimental pathology of diabetes mellitus(Report II). III. Studies on rabbits from ancestors diabetic for several successive generations, especially on spontaneous occurrence of diabetes in $F_{4}$ and $F_{5}$ rabbits, Tohoku J. Exper. Med., 61, 
Suppl., III, 62〜112, 1955.

52）岡本耕造, 赤沢好温, 鈴木昭三 : 歴代糖尿病子孫 $\mathrm{F}_{4}$ ウサギの尿中 ケトステロイドについて，日内分泌誌，33，278～279，昭 32 53) 岡本耕造, 土屋 瑛, 南部四郎： 糖㽷病自然発症ウサギの子孫に関する実験的研究. 雌雄煻尿病自然発症ウサギの子孫について, 東北医誌, 55，313 320, 昭32. 54) 岡本耕造, 翠川 修, 赤沢好温, 山本義明 : 実験的先天性糖尿病動物の尿 中17-KS，17-OHCS 打上びウロペプシンについて，糖尿病，1，94〜97，明33.

55) 岡本耕造 : 実 験的糖尿病の子孫に及ぼす影㗽。月内分泌誌，34，824〜845，炤33。

56) Okamoto, K., Midorikawa, O., Mayama, S., Tashima, E., Sato, T. \& Yamamoto, Y.: On Wistar rats descended from ancestors diabetic for successive generations, especially, on their Langerhans islets and their spontaneous diabetization, Acta Scholae Med. Univ. in Kioto, 36,245 272, 1960.

57) 大野文俊 : 17-KS 亿関学る臨床的知見 補遺，日内分泌誌，31，337〜367，昭31。

58) 小関 要 : 歴代両親 5-(p-Hydroxyphenylazo)-8-hyd-

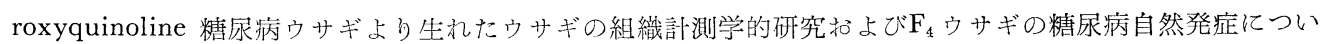
て. 東北医誌，56，523～539，炤32.

59) Pearson, S. \& Glacone, S.: A rapid modification of the Zimmermann test for ketosteroids, J. Clinic. Endocr., 8, 618 619, 1948.

60) Pincus, G. \& Pearlman, W.H. : Fractionation of neutral urinary steroids, Endocrinology, 29, 413 424, 1941.

Pond, M.H. : A microchromatographic method for the separation of certain fractions of 17-KS in human urine, The Lancet, 261, 905 909, 1951.

62) Pond, M.H. : 17-Ketosteroid fractionation stndies by a microchromatographic technique in endocrine disorders, J. Endocr., 10, 202 211, 1954.

Porter, C.C. \& Silber, R.H.: A qualitative colour reaction for cortisone and related 17, 21-dihydroxy20-ketosteroids, J. Biol. Chem., 185, 201 207, 1950.

64) 斎藤達雄, 村木忠雄, 佐々木博司, 植村 順：血管障害合跲糖尿病の尿斦17-KS分劃抢よび17-OHCSについて，糖尿病，1，76〜78，昭33.

斎藤二郎：歴代アロキサン糖尿病シロネズミより生れた幼若シロネズミの内分泌諸臟器細胞, 組織などの計 測的研究. 東北医誌, 57, 703〜 732, 昭33.

66）笹野伸昭，鈴木昭三，岡本豊三 : 同胞に糖尿病自 然発症をみた歴代糖尿病子孫ウサギの出生直後より発症前期にいたる副臂皮質の組織計測学的研究. 東北医 誌，60，594～611，昭34 67）鈴木昭三：正常ならびに歴代両親糖尿病子孫ウサギとくに $\mathrm{F}_{4}$ ウサ ギの尿中17-KSについて，東北医誌，55，468４89，眧32。 68 ）鈴木幸三：尿中17-KS分劃と副腎 皮質. 日内分泌誌，34，768～793，昭33。 69）Sweat, MaxL. \& Farrell, G. : Resolution and quantitative analysis of steroids in adrenal-vein blood, J. Glin. Endocr. \& Met., 12, 968, 1952.

Talbot, N.B. \& Eitingon, I.V. : Urinarysteroids. Use of the periodic acid reaction in the measurement of non-ketonic steroids obtained after various types of hydrolysis, J. Biol. Chem., 154, 605 617, 1944. 71) Talbot, N.B., Wood, M.S., Worcestor, J., Christo, E., Campbell, A.M. \& Zygmuntowicz, A.S. : Further observations on the uninary excretion of watersoluble corticosteroids by normal and abnormal subjects, J. Glinic. Endocr., 11, 1224〜1238, 1951. 72) 竹腰昭道：ペプシノーゲン分泌に関字る研究, 第 6 編。ペプシノーゲンに打よぼすั脳下垂体执よび副腎摘出の影響，48，42〜45，昭34. 吉之助, 広川章子：ウロペプシンの勳態. 南江堂, 東京, 京都, 昭31. コイドに關守る砢究，岐阜紀要，2，462４68，炤30. 75）植手鉄男：尿中コルチコイドに関する 研究. ホルムアルデハイド発生コルチコステロイド測定の呈色干渉について. 岥阜紀要, 4, 136〜142, 昭31. 76) West, Ph.M., Ellis, F.W. \& Scott, B.L. : A simplified method for determining the excretion rate of uropepsin, J. Lab. Clin.Med., 39, 159 162, 1952. 77) White, P. \& Pincus, G. : Heredity in diabetes. The treatment of diabetes mellitus, 8. ed., 769. Lea \& Febiger, Philadelphia, $1947 . \quad 78)$ Wolf, S.M. \& Pashkis, K.E. : Excretion of formaldehydogenic steroids in diabetes, Metabolism, 1, 413〜419, 1952. 79) 山本義明：正常と糖尿病自然発症 Wistar 系シロネズミの子孫に関する実験的研究, 日内 分泌誌，36，1141 1168, 炤35. 80) Zimmermann, W. : Eine Farbreaktion der Sexualhormone und ihre Anwendung zur quantitative colorimetrische Bestimmung, Z. Physiol. Chemie, 233, 257 264, 1935. 81) Zimmermann, W. : Colorimetrische Bestimmung der Keimdrüsenhormone, Z. Physiol. Chemie, 245, 47 57, 1936. 